\title{
İhtisar mı Müstakil Eser mi? Ravzatü'n-nâzzr'ın el-Mustasfâ ile Bağlantısına Dair Bir İnceleme*
}

\author{
Muhammed Usame Onuş ${ }^{* *}$
}

\begin{abstract}
Hanbelî mezhebinin günümüze ulaşan mütekâmil ilk usûl-i fikıh eseri V. (XI.) asrın ortalarında kaleme alınmıştır. Bu tarihten sonra usûl-i fikıh eserleri önceki döneme nispetle daha yoğun bir şekilde kaleme alınmış olsa da söz konusu eserler Mứtezilî ve Eşarî kaynaklara sıklıkla müracaat etmiş, tedris ve telif faaliyetlerine konu olmak açısından mezhepte yeterince ilgi görmemiştir. Fakat İbn Kudâme’nin (ö. 620/1223) Ravzatün-nâzır adlı eseri önceki usûl-i fikıh eserlerinin aksine tedris faaliyetlerinde kullanılmış ve mezhepteki usûl-ı fikıh telifatına kaynaklık etmiştir. Eş̧arî geleneğinin önemli temsilcilerinden olan Gazzâlînnin büyük oranda elMustasfâ adlı eserinden istifade edilerek kaleme alınmış olmasından dolayı Ravzatün-nâzır’’n da önceki eserler gibi ilgi görmemesi beklenebilir. Fakat İbn Kudâme, bazı tasarruflarla eserini el-Mustasfầdan ayrıştırmaya çalışmıştır. Bu çalışmada İbn Kudâme’nin Ravzatün-nâzır’’ elMustasfânın standart bir ihtisarı olmaktan çıkaran ve Hanbelîler'in geleneksel tavırlarına daha yakın bir eser haline getiren tasarrufları üzerinde durulacaktır. Ravzatün-nâzır'daki usul görüşleri ile kelamî uzantıları olan meselelere dair yaklaşımlar, eserde takip edilen sistematik ve kullanılan kaynaklar el-Mustasfâ ile karşılaştırılarak analiz edilecektir.
\end{abstract}

Anahtar Kelimeler: İbn Kudâme, Ravzatün-nâzır, Hanbelî mezhebi, usûl-i fikıh, Gazzâlî, el-Mustasfâ.

Ebû Muhammed (İbn Kudâme) el-Mustasfầnın bablarını almış, kendi görüşüne göre tasarruflarda bulunmuş ve eserini onun üzerine inşa etmiştir. Ya Eb̂̀ Hâmid'in (Gazzâlî) yaptığı gibi babları kutuplar altına taksim etmeye ihtiyaç duymamış veya (Ravza) (Gazzâlînin) eserinin muhtasarı olmasın diye tertibi değiştirerek iki kitap arasındaki farkı göstermek istemiştir. Çünkü o, Ebû Hâmid’in eserini ortaya koyduğu mezhep dişındaki bir mezhep için müstakil bir eser kaleme almaktadır. Zira Ebû̀ Hâmid, Eşarâi ve Şâfî̀ iken Ebû Muhammed, Hanbelî ve Eserî̉dir. ${ }^{1}$

* Çalışmayı baştan sona okuyarak katkılarını esirgemeyen Dr. Orhan Ençakar ve Bayram Pehlivan'a teșekkür ederim.

** Dr. Öğr. Üyesi, Marmara Üniversitesi İlahiyat Fakültesi, ORCID oooo-ooo2-4464-0742 usame.onus@marmara.edu.tr

1 Tûfî, Şerh, I, 98. 


\section{Giriş}

Hanbelî mezhebi teşekkülünden itibaren özellikle fıkıh usûlü ve kelama dair yaklaşımlarıyla diğer mezheplerden farklı özelliklere sahip olmuştur. Diğer mezheplerin ilmî bir disiplin olarak fikıh usûlüyle meşguliyetleri İslam tarihinin nispeten erken dönemlerine kadar giderken Hanbelî mezhebinin bu hususa dair kayda değer ilk çabası V. (XI.) asrın ilk yarısında ortaya çıkmıştır. Ebû Ya'lâ el-Ferrầnın (ö. 458/1066) mezhebin günümüze ulaşan ilk mütekâmil fıkıh usulü eseri el-Udde fì usûli'l-fikh'ı bu çabanın bir ürünüdür. Fakat Ferrâ ile beraber usul eserleri daha yoğun bir şekilde kaleme alınmış olmasına rağmen bu eserlerin mezhepte yaygın bir etkiye sahip olmadığı ve usûl-i fikha dair ilginin yaygınlaşmasına yeterince katkı sağlamadığ söylenebilir. Zira el-Udde’nin yanı sıra Ebü’l-Hattâb el-Kelvezânînin (ö. 510/1116) et-Temhîd fî usûli'l-fikh'1 ile Ebü'l-Vefâ İbn Akîl'in (ö. 513/1119) el-Vâzıh fî usûli'l-fikh'inın başta Mu'tezilî alim Ebü'l-Hüseyin el-Basrînin (ö. 436/1044) el-Mu'temed’i ile Bâkıllânî̉nin (ö. 403/1013) et-Takrîb ve’l-irşâd'1 olmak üzere Mu'tezile veya Eşarîi usul geleneği tarafından üretilen eserlerden istifade ile kaleme alındığı anlaşılmaktadır. ${ }^{2}$ Bu eserler mezhep içerisinde uzun süreli bir etkiye sahip olmamıştır. Mezkûr eserlerin tedris faaliyetlerine veya şerh ve ihtisar yazımına konu olduğuna dair yeterince bilgi bulunmaması da buna işaret etmektedir. Bunun en muhtemel iki sebebi, söz konusu eserlerde mezhebin kelamî problemlere mesafeli tavrıyla çelişen birtakım meselelere yer verilmesi ve onların Hanbelîler'in geleneksel rakibi haline gelmiş olan bazı isim ve gruplarca telif edilen kitaplara dayanıor olmasıdır. Muvaffakuddin İbn Kudâme’nin (ö. 620/1223) Ravzatün-nâzır adlı eserini kaleme aldığg tarihe kadar çoğunluğu Ferrânın öğrencilerinden oluşan Hanbelî alimlerince bazı usul eserleri yazılmış olması mezhepte "Ferrâ ve ashabı"nın usûl-i fikhı daha yoğun bir şekilde işlediğine işaret etse de günümüze ulaşmayan bu eserlerin de benzer endişelerle mezhep gündemini işgal etmemesi, mezhebin genel gündemi açısından kelamî unsurlarla iç içe geçmiş usûl-i fikha dair bu ilgi eksikliğinin devam ettiğini göstermektedir. Bununla beraber İbn Kudâme’nin Ravza'sı her ne kadar bazı eleştirilere muhatap olmuşsa da önceki usul eserlerinin aksine mezhepte

2 Bk. Mübârekî, “Mukaddime”, I, 36, 42-44; Kaya, Mezheblerin Teşekkülünden Sonra Fıkhî İstidlâl, s. 53-56; İbrâhim b. Abdullah, "Tedvînü usûli'l-fikh inde'l-Hanâbile”, s. 130; Özmen, "Doğuşundan Tedvînine Hanbelî Fıkıh Usûlü Geleneği", s. 203-209; İbn Akīl, elVâzıh (Abdullah b. Abdülmuhsin), II, 343; IV, 432; V, 392. Bu konuda değerlendirmeler için bk. Başoğlu, Hicri Beşinci Asır Fıkıh Usulü Eserlerinde İllet Tartışmaları, s. 16-17, 22-23.

3 Bundan sonra esere metin içinde Ravza adıyla işaret edilecektir. 
yaygın bir ilgi görmüş ve mezhep müntesipleri tarafından tedris faaliyetlerinde kullanılmıştır.

Ravza ile Eş'arî geleneğin en önemli temsilcilerinden Gazzâlî̀nin (ö. 505/ 1111) el-Mustasfâ'sı arasındaki benzerlikler İbn Kudâme’nin elMustasfầdan istifadesinin mahiyeti hakkında çeşitli değerlendirmeler yapılmasına sebep olmuştur. Bazı araştırmacılar Ravza'nın el-Mustasfẩnın bir tür özeti olduğunu, ancak eserde mantık mukaddimesine yer verilmesi sebebiyle "felsefe-mantık yönelimli" usul eserleri arasında sayılması gerektiğini öne sürmüştür. ${ }^{4}$ Diğer bir kanaat ise Ravza'nın büyük oranda el-Mustasfâ'dan istifadeyle telif edilmiş olmakla birlikte onun sadece bir özet olarak nitelendirilemeyeceği ve iki eserde yer alan mantık mukaddimelerindeki benzerlikler ve meselelerin vazediliş tarzı dikkate alındığında Ravza'nın "Şâfiî-mütekellimîn usul anlayışının Hanbelî mezhebine giriş sürecindeki en önemli gelişmeyi temsil" ${ }^{5}$ ettiği şeklindedir. ${ }^{6}$ Fakat her hâlükârda Ravza'nın dayandığı temel kaynağın el-Mustasfâ olduğu hususunda ittifak bulunmaktadır. ${ }^{7}$

4 Bk. Dönmez - Köksal, “Usûl-i Fıkıh”, s. 205-204.

5 Ansiklopedi maddesinde Koca, özellikle mantık mukaddimesinde İbn Kudâme’nin Gazzâlî̀den derin bir şekilde etkilendiğini söylemiştir: "Bu iki eserin özellikle mantık ilmini ele alan mukaddimeleri arasındaki benzerlik ve paralellikler Gazzâlî̉nin fıkıh usulü anlayışının İbn Kudâme’yi derin bir şekilde etkilediğini, ayrıca Ravzatün-nâzır'daki kelime seçimi ve meselelerin vazediliş tarzı kaynaklarının başında el-Mustaşfầnın geldiğini göstermektedir. Bu özelliklerinden dolayı Ravzatü’nnâzır, Şâfiî-mütekellimîn usul anlayışının Hanbelî mezhebine giriş sürecindeki en önemli gelişmeyi temsil etmektedir" (Koca, "Ravzatü’n-nâzır”, s. 476). Yazar, farklı bir çalışmasında Gazzâlî̀nin usul anlayışıyla "varlığını kelamî ve felsefi metotlara karşı mücadele etmeye borçlu olan" Hanbelîler arasında bir uzlaşmanın "mantık mukaddimesinin ihtisar edilmesiyle sağlanabilecek derecede kolay” olmayacağ1nı şu şekilde ifade etmiştir: "Zira, önemli olan el-Mustasfầyı ihtisar etmek değil, felsefenin temel dallarından biri olan mantık ilmini fıkıh usulünün mukaddimesi yapan ve usulle ilgili görüşlerini bu mantık ilkeleriyle temellendiren Gazzâlî̉nin usul anlayışıyla kuruluşundan günümüze kadar varlığını kelamî ve felsefi metotlara karşı mücadele etmeye borçlu olan Hanbeliyye’nin görüşlerini uzlaştırmaktır. Bize göre bu uzlaşma, el-Mustasfầnın mantık ilkelerinin tartışıldığı mukaddimesinin ihtisar edilmesiyle sağlanabilecek derecede kolay değildir. Eğer böyle olsaydı, İbn Kudâme'den sonra gelen İbn Teymiyye, ömrünü Şâfiî-Eş'arî kelamcılarıyla mücadele ederek geçirmek zorunda kalmazdı" (Koca, İslam Hukuk Tarihinde Selefî Söylem, S. 124).

6 Nusret Dede de çalışmasında Kocảnın ansiklopedi maddesindeki kanaatlerini tekrarlamaktadır (bk. Dede, İbn Kudâme Penceresinden Fıkıh Usûlü, s. 27-28).

7 İbn Kudâme’nin el-Mustasfầdan istifade ettiğini söyleyen Tûfî, bu iki eseri gören Hanbelîlerin özellikle mantık mukaddimesi sebebiyle benzer kanaatte olduğunu nakletmiştir (Tûfî, Şerh, I, 98). Ravza'yı şerheden İbn Bedrân da İbn Kudâme’nin eserini yazarken Gazzâlîyi takip ettiğini ifade etmiştir (İbn Bedrân, el-Medhal, s. 464; İbn 
İbn Kudâme Ravza'yı büyük oranda el-Mustasfầdan istifade ederek kaleme almış ve hatta bazı ifadeleri harfi harfine iktibas etmiş olmasına rağmen, eserin sadece bir ihtisar olmaktan öte anlamlar taşıdığı anlaşılmaktadır. Nitekim İbn Kudâme, eserinde el-Mustasfầnın tertibinde bazı tasarruflarda bulunmuş, daha önceki Hanbelî alimlerinin usûl-i fikha dair görüşlerini nakletmiş, Hanbelî otoritelerince öne sürülen görüşleri ele almaya gayret etmiş ve meseleleri işlerken ayrıntılarına ileride değinileceği üzere özellikle kelamî problemlerde kendi mezhebinin hassasiyetlerini gözeten önemli tasarruflarda bulunmuştur.

Bu çalışmanın amacı, Ravza'nın ana hatlarıyla Gazzâlìnin el-Mustasfầsını esas almasına rağmen Hanbelîler'in geleneksel olarak nitelenebilecek tavırlarını yansıtan bir fıkıh usulü eseri telif etme amacının ürünü olduğunu göstermektir. Bu bağlamda İbn Kudâme’nin usul görüşleri ile kelamî uzantıları olan meselelere dair yaklaşımları, eserde takip ettiği sistematik ve kullandığ 1 kaynaklar el-Mustasfâ ile karşılaştırılacaktır. Bununla beraber çalışmanın temel odak noktası iki müellifin usul görüşlerini ayrıntılı bir şekilde karşılaştırarak usul anlayışlarını bütün yönleriyle ortaya çıkarmak değildir. Dolayısıyla yapılacak karşılaştırma ve değerlendirmeler seçilen örnekler üzerinden yapılacak ve usul görüşleri uzun uzadıya tartışılmayacaktır. Bu çalışma için iki eserin tamamı gözden geçirilmiş olmasına rağmen özellikle kelamî meselelere dair karşılaştırmaların yapıldığı kısımlar buna dair örneklerin daha görünür olduğu hükmün hakikati, ibâha, mutlak emir gibi meselelerde yoğunlaşmıştır. Bu karşılaştırma sonucunda ortaya çıkan farklılıkların ve benzerliklerin Ravza'yı hangi seviyede el-Mustasfầdan müstakil ${ }^{8}$ bir eser haline getirdiği tespit edilmeye çalışılacaktır. Fakat İbn Kudâme’nin bu eserinin Hanbelîler'in fikıh usulüne dair bakış açılarında ne kadar bir farklılığa yol açtığını ortaya koyabilmek amacıyla İbn Kudâme öncesinde onların bu ilmî disipline karşı olan tavırları özetle gösterilecektir. Zira Hanbelî mezhebinde usûl-i fikıh eseri kaleme alan ilk isim İbn Kudâme olmadığı halde kendisinden önce kaleme alınan usûl-i fıkıh ilmine ve eserlerine mezhep müntesipleri tarafından verilen tepkilerin ortaya

Bedrân, Nüzhe, I, 19). Ayrıca bk. Sâlim, "Mukaddime”, s. 8; et-Türkî, el-MezhebüllHanbelî, II, 216; Sa îd, İbn Kudâme, I, 121; Nemle, "el-Mukaddime”, I, 37; Mirâbî, "Mukaddime", s. 13.

8 Çalışmanın başlığında ve metnin muhtelif kısımlarında yer verilen bu ifade Tûfînin başta alıntılanan yorumundan esinlenerek kullanılmaktadır. Bu kullanım İbn Kudâme’nin eserini kaleme alırken güttügü amacı yansıtmaya yönelik olup Ravza'nın el-Mustasfầdan tamamen bağımsız bir eser olduğu anlamında değildir. Nitekim Tûfî bu ifadeye İbn Kudâme'nin Ravza'yı el-Mustasfầdan farklılaştırmasının sebebini anlatırken yer vermiştir (bk. Tûfî, Şerh, I, 98). 
konması ve buna dair sebeplerin tespit edilmesi Ravza'nın önceki döneme nispetle mezhepte niçin daha yoğun bir ilgiye mazhar olmasını açıklamakta yardımcı olacaktır.

\section{Hanbelîler'in Usûl-i Fıkha Yaklaşımı}

Fıkıh usulü Hanbelîler'in gündemini diğer mezheplere nispetle daha geç bir dönemde meşgul etmeye başlamıştır. Ahmed b. Hanbel'den itibaren Hanbelîler'in hüküm ortaya koyarken belirli prensipler temelinde hareket ettikleri ve ehl-i hadis olarak nitelenen anlayışa uygun bir şekilde Kur'an ve sünnet vurgusunu öne çıaran bir usul izledikleri söylenebilir. Fakat özellikle mütekaddimîn ${ }^{9}$ döneminde usûl-i fikıh ilmine yeterince ilgi göstermedikleri anlaşılmaktadır. Burada kastedilen Hanbelîler'in usûl-i fikha tamamen karşı olmaları değil kelamî unsurlarla bağlantısı sebebiyle usûl-i fikıh ile ilgili meselelerin yoğun bir şekilde gündemi meşgul etmemesidir. Bu sebeple Hanbelîler'in bu tavırlarının doğrudan usûl-i fikha yönelik olmadığını özellikle vurgulamak gerekir. Zira Ahmed b. Hanbel'in görüşlerini toplayarak değerlendiren ve usûl-i fikıh eserlerini III. (IX.) asrın başından itibaren ortaya koyan diğer mezheplerle ${ }^{10}$ neredeyse aynı dönemde muhtasar türünde müstakil ve sistematik fikıh eserlerini kaleme alıp teşekkülünü tamamlayan ${ }^{11}$ bir mezhebin fürû hükümlerini bir metodoloji takip etmeden ortaya koyduğunu söylemek mümkün değildir. Hanbelî mezhebindeki usûl-i fikha yönelik bu ilgi eksikliği daha ziyade usûl-i fikıh ilmine dair faaliyetlerin aklî ve teorik bir düzlemde yürütülmesinin ve bu dönemlerde kaleme alınan eserlerde kelamî

9 Hanbelîler fikıh tarihine dair dönemlendirmede diğer mezheplerin mütekaddimînmüteahhirîn şeklindeki ayırımının aksine mütekaddimîn-mütevassıtîn-müteahhirîn şeklinde üçlü bir ayırım yapmışlardır. Bu ayırıma göre Ferrẩnın (ö. 458/1066) mezhep riyasetine geçmesi mütekaddimîn döneminin sonu ve mütevassitîn döneminin başlangıcı olarak kabul edilmiştir. Dolayısıyla yukarıda "mütekaddimîn” ile Ferrâ öncesi dönem kastedilmektedir (bk. Ebû Zeyd, el-Medhalül-mufassal, I, 135, 217, 463; Kaya, "Mütekaddimîn ve Müteahhirîn”, s. 188; Koca, "Hanbelî Mezhebi”, s. 540).

10 İmam Şâfiînnin (ö. 204/820) er-Risâle’si günümüze ulaşan ilk usûl-i fikıh eseridir (bk. Bedir, "er-Risâle", s. 117). Hanefî mezhebinde ise er-Risâle'den önce fikıh usulü meselelerini içeren risaleler kaleme alındığı ve Ebû Yûsuf'un (ö. 182/798) bir eserinin olduğu nakledilmekle beraber Yılmaz bu eserin bugün anladığımız mânada "usûl-i fikıh ilmi" ile ilgili olmadığını ifade etmektedir (bk. "Hanefi Mezhebinin Rical ve Kitabiyatına Dair Bazı Tetkikat", s. 62-63). Hanefî mezhebinde günümüze ulaşan ilk Hanefî fikıh usulü eseri Cessâs'in (ö. 370/981) el-Füsûl fi'l-usûl'üdür (bk. Özel, "Hanefî Mezhebi", s. 25). Mâlikî mezhebinden ilk usul eseri Ebû Bekir el-Ebherî (ö. 375/986) tarafından kaleme alınmıştır (bk. Kaya, "Mâlikî Mezhebi”, s. 531).

11 Hanbelî fakihi Hırakïnin (ö. 334/946) el-Muhtasar adlı eseri de diğer mezheplerin muhtasar türündeki ilk eserlerini kaleme aldığı IV. (X.) asrın ilk yarısında kaleme alınmıştır (bk. Onuş, Hırakinin el-Muhtasar'i, s. 2). 
mesele ve yöntemlerin kullanılmasının vermiş olduğu menfi intiba sebebiyle olmalıdır. $^{12}$

Hanbelîler' in günümüze ulaşan ilk mütekâmil usul eseri ${ }^{13}$ Ferrâ tarafından telif edilen el-Udde olsa da ondan önce Ebü'l-Hasan et-Temîmî (ö. 371/982), ${ }^{14}$ oğlu Ebül-Fazl et-Temîmî (ö. 410/1019) ${ }^{15}$ ve Ferrầnın hocalarından İbn Hâmid'in de (ö. 403/1012) usule dair eserlerinin olduğu nakledilmiştir. ${ }^{16}$ Fakat bunlar günümüze ulaşmadığı gibi eserler hakkında verilen bilgiler de oldukça sınırlıdır. Ulaşılabilen sınırlı bilgiler arasında söz konusu müellif ve eserlerin kelam ile irtibatını kuran işaretlerin varlığı, onların bu sebeple mezhepte yeterince ilgi görmediği ihtimalini ortaya çıkarmaktadır. Zira Ebül-Hasan et-Temîmî ve Ebü’l-Fazl et-Temîmînin Eşaraî düşüncenin önemli temsilcileri arasında yer alan Bâkıllânî (ö. 403/1013) ile olan yakın dostluklarıyla "Temîmîler’ in Ahmed (b. Hanbel)'in yolundan saptıkları"na dair kanaat beraber zikredilerek bu ikisi arasında bir ilişki olduğu ima edilmiş ${ }^{17}$ ve Temîmîler, Eşarîlere en yakın grup olarak tavsif edilmiştir. ${ }^{18}$ İbn Hâmid'in teşbihe varan görüşlere sahip olduğu nakledilmekle beraber usûl eseri ${ }^{19}$ hakkında kayda değer bir malumata ulaşı-

12 Ehl-i hadisin aklî ve teorik unsurlar içermesi sebebiyle fikıh usulüne mesafeli yaklaştıkları ve bu alanda eser kaleme almakta isteksiz davrandıkları ifade edilmiştir (bk. Dönmez - Köksal, “Usûl-i Fıkıı”, s. 27).

13 Ferrầdan kısa süre önce yaşamış olan İbn Şihâb el-Ukberînin (ö. 428/1037) usûl-i f1kıhla ilgili risalesi de günümüze ulaşmıştır. Fakat bu risale mütekâmil ve sistematik bir usul eseri mahiyetinde değildir (risale hakkında bilgi ve değerlendirme için bk. Ukberî, Risâle, s. 5-20).

14 Ebü'l-Hasan et-Temîmînin eseri ile ilgili kayıtlar için bk. Hatîb el-Bağdâdî, Târîhu Bağdâd, XII, 233; İbn Ebû Ya'lâ, Tabakātü'l-Hanâbile, III, 247; Ziriklî, el-A'lâm, IV, 16.

15 Biyografı ve tarih kitapları Ebü’l-Fazl et-Temîmînin böyle bir eser kaleme aldığını kaydetmemiştir. Bu eserin varlığından Ferrẩnın ona yaptığı atıf sayesinde haberdar olabiliyoruz. Kur'an'da mecaz olup olmamasıyla ilgili olan bu atıf önce Ferrầnın elUdde'sinde daha sonra Ferrâ'dan naklen el-Müsevvede'de yer almaktadır (bk. Ebû Ya 'lâ el-Ferrâ, el-Udde, II, 697; İbn Teymiyye, el-Müsevvede, s. 165).

16 İbn Hâmid'in eseriyle ilgili kayıtlar için bk. Hatîb el-Bağdâdî, Târîhu Bağdâd, VIII, 259; İbn Ebû Ya'lâ, Tabakātü'l-Hanâbile, III, 309.

17 İbn Teymiyye, Ebü’l-Hasan et-Temîmî ve Bâkıllânî arasındaki dostluğun meşhur olduğunu nakletmiştir (İbn Teymiyye, Mecmûu'l-fetâvâ, IV, 167). Zehebî, Ebü'l-Fazl etTemîmî ve Bâkıllânî arasındaki dostluğun yetmiş yıl boyunca devam ettiğini ifade etmiştir (Zehebî, Târîhu'l-İslâm, IX, 152-53).

18 İbn Teymiyye, Mecmûu'l-fetâvâ, IV, 167. Şerafettin Gölcük Ebü'l-Hasan et-Temîmî ile Bâkıllanî arasındaki münazaraların Hanbelîler'in kelama dair tavırlarında yumuşamaya sebebiyet verdiğini ifade etmiştir (Gölcük, "Bâkıllânî”, s. 531).

19 İbn Hâmid'in Tehzîbü̉l-ecvibe adlı eserinin de bir usûl-i fikıh eseri olarak değerlendirilmesi gerektiğine dair kanaatler sorgulanmalıdır (bu kanaatler için bk. Kāyidî, "el-Mukaddime", I, 16; Sâmerrâî, "Mukaddimetü'l-muhakkık", s. 5). Zira bu eser daha ziyade Ahmed b. Hanbel'in görüş beyan ederken kullandığı bazı kavramların anlamını ortaya koymayı amaçlamaktadır. Ayrıca İbn Hâmid'in usule dair meselelere yer 
lamamıştır. Bununla birlikte İbn Teymiyye de İbn Hâmid'in teşbihe varan görüşlere sahip olduğunu ifade etmiştir. ${ }^{20}$ Hanbelîlerin sıklıkla muhatap olduğu böyle bir eleştirinin Hanbelî bir âlim tarafından başka bir Hanbelî âlim için yapılmış olması, İbn Hâmid’e yönelik eleştirilerin onun sadece kelâmla ilgili görüşlerinden kaynaklanmadığını, aynı zamanda kelamî problemlerle iştigal ederek Hanbelîlerin "sükût etme" ve "bilâkeyf" iman etme anlayışlarına aykırı davranmasıyla da ilişkili olduğunu göstermektedir. Bu durum eserinin mezhep müntesipleri tarafından hakkında bilgi verilmeyecek kadar ilgi görmemesinin sebepleri arasında sayılabilir.

Literatürde kelam ile iştigal etme açısından Hanbelî mezhebinde bir yumuşamanın ilk işaretlerinin İbn Hâmid'de görüldüğü ifade edilse $\mathrm{de}^{21}$ buna dair nispeten daha etkili gelişmelerin Ferrâ ile birlikte ortaya çıtığg söylenebilir. Ferrẩnın kaleme aldığı usul eseri mezhebin yerleşik tavrına aykırı tartışmalara yer verdiği halde günümüze ulaşabilmiş ve daha da önemlisi söz konusu tartışmalar "Ferrầnın ashabı"22 olarak nitelenen bir ulema grubu tarafından devam ettirilmiştir. Bu alimler arasında Ferrẩnın önde gelen öğrencilerinden Ebü'l-Hattâb el-Kelvezânî ile (ö. 510/116) Ebü'l-Vefâ İbn Akīl (ö. 513/1119) en dikkat çeken isimlerdir.

V. (XI.) asrın ortalarına gelindiğinde Bağdat Hanbelîleri arasında mezhebin önde gelen ismi Ferrânın öncülügünde kelama ve onunla yakından irtibatlı olan usûl-i fikha daha müspet yaklaşan bir eğilim ortaya çıkmış ancak yine de mezhebin ana çizgisindeki eleştirel tavır hâkim söylem olmaya devam etmiştir. el-Udde esas itibariyle Mu'tezilî usulcü Ebü'l-Hüseyin el-Basrî, Mâlikî-Eş'arî usulcü Bâkıllânî ve Hanefî-Mu'tezilî²3 usulcü Cessâs’in eserlerinden besleniyordu. Önceki dönem fikıh usulü müelliflerinin aksine Kelvezânî ve İbn Akil gibi güçlü isimlerin Ferrầnın bu eserini gerek içerik gerekse kaynak açısından takip etmesi mezhepte ilk defa kelama dair tartışmaların önceki dönemlere nispetle daha uzun soluklu bir şekilde gündemde kalmasını sağlamıştır. ${ }^{24}$ Bununla beraber Ferrânın teşbih ve tecsime

vermenin Tehzîbül-ecvibe’nin amacına uygun olmadığını söyleyerek okuyucuyu kendi usul eserine yönlendirmesi de Tehzîbü'l-ecvibe'yi bir usul eseri olarak kaleme almadığını göstermektedir (İbn Hâmid, Tehzîbüll-ecvibe (Sâmerrâî), s. 193).

20 İbn Teymiyye, Mecmûu'l-fetâvâ, VI, 54 .

21 İbrahim Aslan Hanbelî mezhebi içinde kelam yapmaya götüren çabaların mezhepte İbn Hâmid ile başladığını ifade etmektedir (Aslan, "el-Usûlül-Hamse’nin Hanbelî Yorumu", s. 58).

22 Literatürde geçen "Ferrâ ve ashabı" nitelemesi hakkında ayrıntılı bilgi için bk. Onuş, VI.-VII. Asırlarda Dımaşk Hanbelîliği, s. 147-51.

23 Cessâs'in Mưtezilî olmasıyla ilgili kanaat için bk. Özen, Eb̂̂u Mansûr el-Mâtürî̀înin Fıkıh Usûlünün Yeniden İnşası, s. 155-56.

24 İbn Akỉl'in eserini tahkik eden George Makdisi, el-Vâzıh'in sadece bir usul eseri 
varan görüşleri sebebiyle mezhebe "kıyamete kadar temizlenemeyecek bir kir bulaştırdığı" 25 şeklinde eleştirilmesi ve ayrıca Hanbelîler tarafından İbn Akil'in ölümüne fetva verilmesi ${ }^{26}$ mezhebin eleştirilere konu olan meseleleri içeren disiplin ve eserlere dair katı tutumunun aynı sertlikle devam ettiğine işaret etmektedir. Ferrầnın hem tecsim ve teşbih ile suçlanması hem de eserinde Mútezilî ve Eşaraî kaynaklarına yaslanması birlikte düşünüldügünde ona ve kendisini takip edenlere yönelik tepkilerin sadece sahip oldukları görüşlere dair değil daha ziyade bu görüşlere ulaşırken Hanbelîler'in Ahmed b. Hanbel'den itibaren süregelen kelamî hususlarda "bilâkeyf" iman etme ve "sükût etme" prensibini ihlal etmelerinden kaynaklandığını söylemek mümkündür.

Ferrầnın el-Udde'sinden İbn Kudâme’nin Ravza'yı kaleme almasına kadar geçen süreçte Kelvezânî ve İbn Akỉ dışında da usul eserleri telif eden birçok alim olmuş fakat bu eserler günümüze ulaşmamış ve literatürde onlardan çok bahsedilmemiştir. ${ }^{27} \mathrm{Bu}$ dönemde usul eseri kaleme alan müelliflerin büyük çoğunluğunun Ferrầnın öğrencisi olması veya bu öğrencilerden ders alan ve Ferrẩnın temsil ettiği eğilimi takip eden isimlerden oluşması dikkat çekicidir. ${ }^{28}$ Bu husus göz önünde bulundurulduğunda söz konusu eserlerin Ferrâ ve ashabının yazım yöntemini takip etmesi ve muhtemelen içinde kelama dair unsurlar barındırması, onların mezhep müntesipleri tarafından göz ardı edilmesinin en muhtemel sebeplerinden biri olabilir.

Hanbelî mezhebinde motivasyonunu kelama karşı olan menfi tavırdan alan benzer tepkiler İbn Kudâme’nin Ravza'sına karşı da gösterilmiştir. İbn Kudâme ile aynı dönemde yaşayan İshak b. Ahmed el-Alsî (ö. 634/1236-37) İbn Kudâme'yi el-Mustasfầda bulunan mantık mukaddimesini de özetlemesi sebebiyle tenkit etmiştir. ${ }^{29}$ Fakat bu eleştirinin, Ferrâ ve ashabına yapılan eleştirilerin aksine marjinal kaldığ 1 anlaşılmaktadır. Zira İbn Kudâme ve eseri hakkında bilgi veren kaynaklarda onun şahsına ya da eserine yöneltilen ve kelama veya usule dair yaklaşımını hedef alan bir eleştiriye rastlanmamıştır. Hatta tam aksine tabakat müellifi ve Hanbelî fakihi İbn Receb (ö. 795/1393),

olmadığını aynı zamanda diğer usul eserlerinde bulunmayan bir istidlal yöntemi teklif ettiğini ve bütün İslamî ilimler için önemli bir fonksiyonu yerine getirdiğini ifade etmektedir (Makdisi, "Mukaddimetü’l-muhakkık”, II, m1-m2; III, m1-m2).

25 Bk. Safedî, el-Vâfî, III, 8; İbnü’l-Esîr, el-Kâmil, VIII, 378.

26 İbn Receb, Zeyl, I, 322; İbnü'l-Esîr, el-Kâmil, IX, 190.

$27 \mathrm{Bu}$ dönemde kaleme alınan usul eserlerinin bir listesi için bk. Ebû Zeyd, el-Medhalü'lmufassal, II, 942-44.

$28 \mathrm{Bu}$ isimlerin Ferrâ ile bağlantısı için bk. Onuş, VI.-VII. Asırlarda Dımaşk Hanbelîliği, s. 146-47.

29 Tûfî, Şerh, I, 100. 
İbn Kudâme’nin kelamî tartışmalara girmeyi hoş karşılamadığını ve bu tartışmaların temel konularından olan sıfatlar meselesinde "tefsir, tekyîf, temsil, tahrif ve ta 'tîle başvurmadan" naslarda geçtiği şekliyle görüş beyan ettiğini ifade ederek onun Hanbelîler'in Ahmed b. Hanbel'den itibaren süregelen tavrına sadık kaldığını vurgulamıştır. ${ }^{30} \mathrm{Bu}$ sebeplerden dolayı olacak ki Ravza diğer usul eserlerinin aksine Hanbelîler tarafından çokça okunan bir eser haline gelmiştir. Hatta İshak b. Ahmed el-Alsî eserin yayıldığını görünce eleştirilerine konu ettiği mantığa dair mukaddimeyi Hanbelîler' in kelam ve mantık ilmiyle iştigal edeceği endişesiyle muhtemelen ya okurken ya da istinsah ederken Ravza'dan çıkarmayı tercih etmiştir. ${ }^{31}$

İbn Kudâme’nin eserini Hanbelî olan Ferrâ, Kelvezânî veya İbn Akîl'in eserleri yerine Şafiî bir isim olan Gazzâlînin eserine dayandırması bu üç ismin eserlerindeki Mưtezilî izlerden uzaklaşma çabası olarak açılanabilir. Bununla beraber İbn Kudâme’nin yaşadığı dönemde Hanbelîler'in Eş'arîler'le olan muhalefeti göz önünde bulundurulduğunda Eşsarî geleneğin önemli temsilcilerinden olan Gazzâlînnin eserini de esas almaması beklenir. Fakat bu durumu iki şekilde açıklamak mümkündür:

1. Söz konusu dönemde Hanbelî çevrenin Eşárî anlayışa olan bakış açısı önceki dönemlerde Mutezilî anlayışa karşı olan bakış açısından daha yumuşak bir hal almış olabilir. 2. Mutezile’nin Mihne döneminden sonra güç kaybetmesinden dolayı gittikçe güçlenen ve Gazzâlî ile beraber ehl-i sünnet geleneğinin entelektüel faaliyetlerinin yürütüldüğü neredeyse yegâne mecra haline gelen Eşáaî düşünce ile olan irtibatını -Eşáâi geleneğin en güçlü temsilcisi konumunda olan Şâfiîlerin etkin ve yönlendirici bir güç olduğu Dımaşk’taki ilmî ortamın Hanbelîleri zorlamasının da etkisiylebir şekilde kurma isteği olarak değerlendirilebilir. ${ }^{32}$

Fakat Ravza'nın Ferrâ ve ashabının kaleme aldığı eserlerden farklı olarak kelamî unsurlardan büyük oranda arındırılarak kaleme alınması ve Hanbelî kaynaklardan da yoğun bir şekilde faydalanması eserin kabul görerek yaygınlaşmasında daha belirleyici olmalıdır. Zira İbn Kudâme, eserinin temel kaynağ1 olarak Eş̧arî geleneğin en güçlü isimleri arasında kabul edilen Gazzâlînnin el-Mustasfầsını esas alsa da eserin içerik ve tasnifinde bazı tasarruflarda bulunarak Hanbelî geleneğe daha uygun bir usul çıarma amacı gütmüş gibidir.

30 İbn Receb, Zeyl, III, 291.

31 Bk. Tûfî, Şerh, I, 100.

32 Onuş, VI.-VII. Asırlarda Dımaşk Hanbelîliği s. 126-27. İbn Kudâme’nin yaşadığ dönemde Dımaşk'taki Hanbelî çevre hakkında ayrıntılı bilgi için bk. Onuş, VI.-VII. Asırlarda Dımaşk Hanbelîliği, s. 31-75. 


\section{Ravzatü’n-nâzır'ı Müstakil Bir Eser Haline Getiren Unsurlar}

Ravza ile el-Mustasfâ arasındaki bağlantı dikkate alındığında İbn Kudâme’nin eserini Hanbelî geleneğine yaklaştıran tasarruflarının çoğu aynı zamanda onu el-Mustasfầdan farklılaştıran unsurlar olarak öne çlkmaktadır. İki eser arasındaki benzerlikler dikkat çekici seviyede olsa da İbn Kudâme’nin kelamî bağlantıları olan meselelere, kullandığı kaynaklara, eserinin tasnifine ve usul görüşlerine dair tasarrufları Ravza'nın farklı bir kimliğe bürünmesini sağlamaya yöneliktir. Nitekim Tûfî de İbn Kudâme’nin söz konusu tasarruflarını ve eserinde Gazzâlî ile el-Mustasfầdan hiç bahsetmeme sebebini müellifin iki eser arasındaki farkı ortaya koyma ve kendi eserinin el-Mustasfầnın ihtisarı olarak algılanmasının önüne geçme amacına bağlamaktadır. Ayrıca Tûfî, Gazzâlînnin Eşarîi-Şâfiî kimliğine vurgu yaparak “Hanbelî-Eserî” olan İbn Kudâme’nin kendi mezhebine dair müstakil bir eser ortaya koyma amacında olduğunu belirtmektedir. ${ }^{33}$

\section{Kelamî Uzantıları Olan Meselelere Dair Yaklaşımlar}

Ravza'yı el-Mustasfầdan farklılaştırarak onu "Hanbelî-Eserî" bir fikıh usulü kitabı haline getiren hususların başında İbn Kudâme’nin kelamî uzantıları olan meselelerde ortaya koyduğu yaklaşım gelmektedir. Gazzâlî her ne kadar eserinin girişinde usûl-i fikhın kelamdan bağımsız bir ilim olması gerektiğini ve dolayısıyla eserinde kelamî problemlere mümkün mertebe yer vermeyeceğini ${ }^{34}$ söylese de kelamî uzantılarına değindiği birçok mesele mevcuttur. İbn Kudâme ise bunlara yer vermeyerek Hanbelîler' in "bilâkeyf" iman etme ve "sükût etme" tavrını devam ettirmiştir.

\section{a. Mantık Mukaddimesindeki Örnekler}

İbn Kudâme soyut kavramların ve meselelerin usûl-i fikha nispetle daha yoğun bir şekilde ele alındığı mantık mukaddimesinde bu soyutlamalardan büyük oranda uzak durmaya çalışmış ve Gazzâlînnin çoğunlukla örneklemelerde kullandığı kelamî hususları eserine almamıştır. Mesela Gazzâlî burhanın tanımıyla ilgili bölümde Allah’n, kişinin mukaddimelerden oluşan mürekkep bilgisini o mukaddimeler olmadan bir şekilde yaratmaya muktedir olmakla vasıflanamayacağını ifade ederken, İbn Kudâme büyük ihtimalle bunu Allah’ın kudretine bir müdahale olarak algılamış ve bu hususa hiç değinmemiştir. ${ }^{35}$

33 Bk. Tûfî, Şerh, I, 98.

34 Gazzâlî, el-Mustasfâ, s. 9.

35 Bk. Gazzâlî, el-Mustasfâ, s. 25; İbn Kudâme, Ravzatün-nâzır, s. 37. 
Arap dilinde marife edatı alan lafızların umum ifade etmesi gerektiğini söyleyen Gazzâlî, kendisine yöneltilen eleştiriler arasında yer alan "el-ilâh" sözcüğünün marife edatı aldığı halde tek bir zata delaletiyle alakalı açıklamasında dilin vâzıının birden fazla ilahın olmasını mümkün görmesi halinde bu sözcügün de bütün ilahlar için umum ifade edeceğini söylemekte ve bu örnekte umum ifade etmemesini sözcüğün mefhumuna bağlamaktadır. İbn Kudâme ise Gazzâlî̉nin yaptığı gibi uzun açıklamalar yapmak yerine meseleye kısaca değinmekte ve benzer hususu savunmasına rağmen sadece “eş-şems" sözcügünü örnek göstererek "el-ilâh" sözcügünü zikretmekten ve yorumlamaktan özellikle kaçınmaktadır. ${ }^{36}$

Öte yandan Gazzâlî telâzüm bahsinde örnek olarak âlemin hudusunu ve Allahin muhdis (yaratıcı) olmasını içeren mukaddimeleri ve bunların yol açtığı neticeyi zikrederken, İbn Kudâme bundan dahi kaçınmış ve namaz ile abdest arasındaki ilişkiyi örnek göstermiştir. Telâzüm (iki şeyin karşılıklı olarak birbirini gerektirmesi) yöntemi meselesinde de Gazzâlî, fıkıh mesâilini içeren örneklerin yanında Allahìn arşa yerleşmesinin muhal olması gibi kelamî çağrışım ve uzantıları güçlü olan bir örnek daha verirken İbn Kudâme yine abdest-namaz ilişkisine ve abdestin namazın sıhhatine etkisine dair örneği zikretmekle yetinmiştir. ${ }^{37}$ Ayrıca Gazzâlînin kelamî problemlere değindiği birçok meseleyi İbn Kudâme, bu problemlerden arındırarak çok daha muhtasar bir biçimde ele almıştır. ${ }^{38}$ Burhanın kısımlarına dair meselede Gazzâlînnin kelamî bağlantısını özellikle vurguladığı örneğin ${ }^{39}$ Ravza'da yer almaması da İbn Kudâme’nin bu husustaki hassasiyetini göstermektedir. ${ }^{40}$

\section{b. Hüsün-Kubuh Meselesiyle İlgili Örnekler}

Mantık ilmine dair mukaddimede kelama karşı olan mesafeli tavır büyük ölçüde ilgili meselelerde işlenen tikel bazı örnekler üzerinde görülebiliyorsa da kelamın konusunu oluşturan küllî meselelerde de benzer bir tavra rastlanır. Bunlar arasında en dikkat çekici olanı hüsün-kubuh (iyilik-kötülük) tartışmalarıdır. Gazzâlî hüküm bahsinde hükmün hakikatiyle (tanımı) konulara başlarken kelamî mezhepleri birbirinden ayıran temel hususlardan biri olan

36 Bk. Gazzâlî, el-Mustasfâ, s. 26; İbn Kudâme, Ravzatünn-nâzır, s. 39.

37 Gazzâlî, el-Mustasfâ, s. 33; İbn Kudâme, Ravzatün-nâzır, s. 45.

38 Gazzâlî, el-Mustasfâ, s. 39-40; İbn Kudâme, Ravzatün-nâzır, s. 47.

39 Gazzâlînnin bu hususta verdiği örnek şu şekildedir:

Muhkem olan her fiilin fâili alimdir.

Âlem de muhkem bir fiildir.

O halde âlemin yaratıcısı da alimdir (Gazzâlî, el-Mustasfâ, s. 43).

40 Bk. Gazzâlî, el-Mustasfâ, s. 43; İbn Kudâme, Ravzatün-nâzır, s. 51. 
hüsün-kubuh meselesine müstakil olarak yer vermekte ve eserinin ilerleyen bölümlerinde bu meseleyle irtibatlı konularda da bazı değerlendirmelerde bulunmaktadir.

Eş́arî geleneğine mensup bir alim olarak aklın bir şeyi hasen (iyi) ya da kabih (kötü) görmesinin ve bunun üzerine hüküm inşa etmesinin mümkün olmadığını ve ayrıca fiillerdeki hüsün ve kubhun zatî değil itibarî olduğunu ifade eden Gazzâlî, hükmün ancak şâriin hitabı ile ortaya çıkacağını savunmakta ve aksini iddia eden Mu'tezile'nin görüşüne atıfta bulunarak onu çeşitli argümanlarla çürütmeye çalışmaktadır. ${ }^{41}$ İbn Kudâme ise Ravza'nın girişinde eserinin birinci babının "Hükmün Hakikati ve Kısımları"na ${ }^{42}$ dair olduğunu ifade etmesine rağmen hükmün hakikati ve hüsün-kubuh meselesine hiç değinmeyerek sadece hükmün kısımlarını açıklamakla yetinmiştir. ${ }^{43}$ Ayrıca Gazzâlî mübah, ${ }^{44}$ nesih ${ }^{45}$ ve mutlak emrin fevr veya terâhîye delalet etmesi ${ }^{46}$ gibi konularda bunların hüsün-kubuh ile alakalı yönlerine de yer verirken İbn Kudâme söz konusu konuların hüsün-kubuhla alakalarına değinmemiştir. ${ }^{47}$

\section{c. Delillerle İlgili Örnekler}

İbn Kudâme kelamî meselelere karşı mesafeli tavrını haber-i vâhidin ilim gerektirip gerektirmeyeceğine ilişkin meselede açık bir şekilde göstermektedir. O, selefin haber-i vâhitlerin her ne kadar ameli zorunlu kılmasa da sıfatlar konusunda nakledilmesi gerektiği hususunda ittifak ettiğgini aktarır. Fakat bununla söz konusu rivayetleri itikadî meselelerde bir delil olarak kullanmaktan ziyade ilgili konulara dair rivayetlerin nakledilerek mevcudiyetinin ispat edilmesi ve içeriğinin olduğu haliyle tasdik edilmesinin amaçlandığını kastetmektedir. Nitekim haber-i vâhitlerin itikadî konularla ilgili kullanılması halinde sağlayacağı yararı bu rivayetleri olduğu gibi "tasdik etmenin vücubu ve bu haberlerin içeriğine itikat etmek” şeklinde açıklamaktadır. Böylece sıfatlar konusundaki tavrın tasdik ve itikaddan öteye gitmemesi dolayısıyla bunlara dair herhangi bir tevilin yapılmaması gerektiğine işaret etmiştir. ${ }^{48}$

41 Bk. Gazzâlî, el-Mustasfâ, s. 45-49. Gazzâlî eserinin henüz başında "Hükmün Hakikati”" başlığında okuyucunun aklın hüsün ve kubuhta rolü olmadığını anlayacağını ifade etmektedir (Gazzâlî, el-Mustasfâ, s. 8).

42 İbn Kudâme, Ravzatün-nâzır, s. 26.

43 Bk. İbn Kudâme, Ravzatün-nâzır, s. 53 vd.

44 Gazzâlî, el-Mustasfâ, s. 59-60.

45 Gazzâlî, el-Mustasfâ, s. 85 .

46 Gazzâlî, el-Mustasfâ, s. 211.

47 Bk. İbn Kudâme, Ravzatün-nâzır, s. 68, 98, 240.

48 İbn Kudâme, Ravzatünn-nâzır, s. 127. 
Gazzâlî, özetle bir hükmün şer'in vürudundan önceki hali üzere kalması anlamına gelen aslî nefiy meselesinde yokluğun bir illete sahip olmadığını ifade ederek âlem yaratılmadan önce âlemin ezeldeki yokluğu için bir illetten söz edilemeyeceğini söyleyip buna dair kelamî hususlara değinmiş, ${ }^{49}$ kıyas bahsinde illeti işlerken aklî illet ile şer î illet arasındaki farklılığı izah ettiği sırada bazı kelamî nakillerde bulunmuştur. ${ }^{50}$ İbn Kudâme bu meselelere eserinde yer vermesine rağmen kelamî yönü olan örnek ve açıklamalardan özellikle kaçınmış gibidir. ${ }^{51}$

\section{d. Elfaz Bahisleriyle İlgili Örnekler}

Gazzâlînnin elfaz bahislerinde kelamî örneklere yer vererek işlediği meseleler Ravza'da da mevcuttur. Fakat İbn Kudâme’nin bu meseleleri işlerken kelam ile ilgisi olan örnekleri zikretmemesi yukarıdaki kanaati desteklemektedir. Mesela Gazzâlî emir bahsinde emir-irade arasındaki ilişki bağlamında Mu'tezile’nin emrin iradeden bağımsız olamayacağı görüşüne atıfta bulunup onlara cevap verirken, ${ }^{52}$ İbn Kudâme de yine Mu'tezile’nin görüşünü zikretmekle birlikte bu görüşün kelamî uzantılarını içeren örneklere yer vermemektedir. ${ }^{53}$ Benzer bir tavır karinelerden soyutlanmıs olarak vârit olan emrin ifade edeceği anlam ile ilgili meselede de mevcuttur. Gazzâlî, Mu'tezile’nin bu tür bir emrin nedb ifade edeceğine ilişkin görüşüne uzun uzadıya cevaplar verirken, İbn Kudâme muhtemelen meselenin kelamî uzantılarından kaçınmak amacıyla bu görüsse kısaca değinmektedir. ${ }^{54}$

\section{e. İçtihat-Taklit Meseleleriyle İlgili Örnekler}

Gazzâlî, içtihadda hata-isabet meselesinde Cehmiyye ve Mürcie’nin önde gelen otoriteleri arasında yer alan Bişr b. Gıyâs’n (ö. 218/833) ve diğer bazı önemli isimlerin aklî meselelerde olduğu gibi fikhî konularda hata yapanın da günahkâr olacağ uzadıya eleştirmiştir. ${ }^{55}$ İbn Kudâme ise, söz konusu görüş ve cevaplardaki kelamî uzantılardan dolayı olsa gerek ilgili meselede Bişr b. Giyâs'tan hiç bahsetmemiştir. Fakat İbn Kudâme'nin aynı meselede Hanefî fakihi Ubeydullah b. Hasan el-Anberînin (ö. 168/784) "Her müçtehit musîbdir" şeklindeki

49 Gazzâlî, el-Mustasfâ, s. 329.

50 Gazzâlî, el-Mustasfâ, s. 332.

51 Sirasiyla bk. İbn Kudâme, Ravzatün-nâzır, s. 389, 368.

52 Gazzâlî, el-Mustasfâ, s. 203-204.

53 İbn Kudâme, Ravzatün-nâzır, s. 234-35.

54 Gazzâlî, el-Mustasfâ, s. 207; İbn Kudâme, Ravzatünn-nâzır, s. 235.

55 Gazzâlî, el-Mustasfâ, s. 350-52. 
görüşüne cevap verirken şaşırtıcı bir şekilde kelamî olarak nitelenebilecek bazı tartışmalara girdiği, hatta Anberînin söz konusu görüşünü sofistlerle ilişkilendirdiği ${ }^{56}$ görülmektedir. Fakat Gazzâlî, Anberînin mezkûr görüşüne yer verirken onun kendi içinde çelişkili olduğunu göstermek amacıyla, "Âlem aynı anda nasıl hem hâdis hem kadim olabilir?" ve "Yaratıcının hem varlı̆̆ hem yokluğu nasıl mümkün olabilir?" gibi kelamî sorular sorup bunlara dair bazı açıklamalar yaparken, ${ }^{57}$ İbn Kudâme ise sadece ilgili soruları tekrar etmekle yetinip ayrıntılara girmeden Anberînin görüşündeki çelişkiye vurgu yapmaktadır. İbn Kudâme'nin bu meselede sadece sorularla yetinip bunların zeminini oluşturan kelamî tartışmalara hiç girmemesi eserin geneline yayılan tavriyla uyumludur.

Diğer bir örnek müçtehidin şartlarıyla ilgili meselededir. Gazzâlî müçtehit olmanın şartlarını sayarken müçtehidin bir kelamcı gibi kelam yöntemine vâkıf olmasa bile en azından Allahin zat ve sıfatlarıla alakalı bazı hususları bilmesi gerektiğini ifade ederken İbn Kudâme böyle bir şarttan bahsetmemektedir. ${ }^{58}$

\section{Görüş Farklılıkları}

İbn Kudâme'nin eserinin el-Mustasfầnın ihtisarı olmaktan öte anlamlar taşıdığını ve Hanbelî usul eseri olarak tavsif edilmesi gerektiğini gösteren en önemli unsurlardan biri de, onun Gazzâlî ile muhalefet içinde olduğu meselelerde kendisinin ve mezhebinin görüşünü savunması ve bunu yaparken Gazzâlînnin görüşünü eleştirilerinin merkezine yerleştirmesine rağmen ne Gazzâlînnin ne de eserinin adını anmasıdır. Hatta bazı meselelerde Gazzâlînin muhalif görüş olarak zikredip eleştirdiği yaklaşımları kendi görüşünü destekleyici argümanlar olarak yeniden düzenlemiştir.

\section{a. Delillerle İlgili Örnekler}

İbn Kudâme şer î delilleri sıralarken Gazzâlî̀yi takip etmiştir. Aslî delilleri Kur'an, sünnet, icmâ ve istishap şeklinde sıralamakta ve Gazzâlînin mevhum deliller olarak işlediği șer'u men kablenâ, sahâbî sözü, istihsan ve istislah delillerine ise aynı sıralama ile hakkında ihtilaf bulunan deliller olarak yer vermektedir. Kıyas ise her iki eserde de deliller arasında yer almamış ve bir yöntem olarak değerlendirilmiştir.

Şerî delillerin tasnifine dair yukarıdaki benzerliklere rağmen içerikte bazı meselelerde İbn Kudâme’nin farklılaştı̆̆ı görülür. Mesela Gazzâlî, kıyası “...

56 İbn Kudâme, Ravzatü’n-nâzır, s. 417.

57 Gazzâlî, el-Mustasfâ, s. 349 .

58 Gazzâlî, el-Mustasfâ, s. 343-44; İbn Kudâme, Ravzatün-nâzır, s. 408. 
malumu maluma hamletmek" olarak tanımlarken İbn Kudâme, tanım tekniği açısından Gazzâlînin eleştirisine konu olan “... fer'i asla hamletmek” şeklindeki tanımı yapmıştır. Hanbelî ulemasının ve Gazzâlînnin kıyas tanımlarına zayıflık anlamı içeren "kil" (söylendi) lafzıyla yer vermesine rağmen, bu tanımların birbirine yakın olduğunu belirtip aslına dair bir eleştiride bulunmamıştır. ${ }^{59}$

Nesih konusunda da Gazzâlî farklı argümanlarla ve yapılan itirazlara cevaplar vererek Kur'an’ın sünnet ile neshini mümkün görürken İbn Kudâme meseleye kısaca değinmiş ve bunun aklen caiz olmasına rağmen şeran caiz olmadığını belirterek haber-i vâhidin Kur'an’’ neshedemeyeceğini savunmuştur. ${ }^{60}$

İbn Kudâme kāsır illetle ${ }^{61}$ ta lîl meselesinde kendini Gazzâlînin karşısında konumlandırmakta ve nispeten daha sert karşılıklar vermektedir. Gazzâlî kāsır illetle ta'lîlin caiz olduğunu ifade etmiş ve buna gelen itirazlara cevaplar vermiştir. ${ }^{62}$ Aksi görüşü savunan İbn Kudâme Gazzâlînnin itiraz olarak zikrettiği argümanları kendi görüşünü desteklemek için kullanırken, Gazzâlînnin cevaplarını ise kendi görüşüne itiraz olarak sunmuştur. Fakat verdiği cevaplarda eserinin tamamında olduğu gibi Gazzâlîyi zikretmemiş, bu görüşleri genelde Şâfiiler'e nispet ederek cevaplarını sıralamış ve en nihayetinde muhalif görüşü "tahakküm” ${ }^{63}$ olarak nitelemiştir. ${ }^{64}$

\section{b. Elfaz Bahisleriyle İlgili Örnekler}

Elfaz bahislerinde ise İbn Kudâme "yasaklamadan sonra gelen emrin delaleti” meselesinde bu emrin ibâhaya delalet ettiğini savunurken, Gazzâlî̉nin özetle "eğer yasaklama muallel ise söz konusu emrin ibâhaya, değilse nedb ya da ibâha muhtemel olduğu fakat bir karine sebebiyle ibâhanın öncelenmesi gerektiği ve emrin emir kalıbı ile gelmemesi durumunda nedb veya icaba muhtemel olduğu" yönündeki görüşüne ayrıntılara yer vermeden "Bir grup dedi” şeklinde kapalı bir üslupla atıf yapmıștır. Ayrıca Gazzâlînnin ilk sırada zikrettiği ibâha görüşüne, "bizim görüşümüz gibi” ifadesini iliştirerek

59 Bk. Gazzâlî, el-Mustasfâ, s. 280; İbn Kudâme, Ravzatü’n-nâzır, s. 321.

60 Bk. Gazzâlî, el-Mustasfâ, s. 100; İbn Kudâme, Ravzatünn-nâzır, s. 113.

61 Kāsır illet sadece asılda bulunan ve kendisiyle kıyas yapılamayan hususi bir vasfı ifade etmektedir. Bununla beraber kāsır illet ile ta'lîlin caiz olup olmadığı tartışmalı bir meseledir (bununla ilgili ayrıntılar için bk. Çalış, "Kâsır İlletle", s. 89-74).

62 Gazzâlî, el-Mustasfâ, s. 338-40.

63 Tahakküm "bir konuda delil olmadan hüküm vermek" anlamına gelmektedir. Bu ifade Yunus Apaydın tarafından bazı yerlerde olduğu gibi bırakılırken bazı yerlerde ise "keyfî hüküm" olarak tercüme edilmiştir (bk. Gazzâlî, Mustasfâ: İslam Hukukunun Kaynaklarl, s. 132, 691, 832, 931).

64 İbn Kudâme, Ravzatün-nâzır, s. 369-73. 
bunun aslında Hanbelî mezhebinin görüşü olduğunu vurgulamıştır. Ardından Gazzâlînnin mezkûr görüşünü temellendirmek için zikrettiği delilleri ilginç bir biçimde kendisinin ibâha görüşüne uyarlayarak tekrar kaydeden İbn Kudâme, kendisine yöneltilmesi muhtemel olan ve el-Mustasfầda yer almayan bazı itirazlara da cevaplar vermiştir. ${ }^{65}$

Mutlak emrin fevre mi, yoksa terâhîye mi delalet ettiği tartışmasında da İbn Kudâme ile Gazzâlî farklı görüşleri savunmaktadırlar. Mutlak emrin fevre delalet ettiğini söyleyen İbn Kudâme, bu görüşü savunurken sadece kendi delillerini sunmamakta, aynı zamanda Gazzâlînin eserinde yer verdiği itirazlara da cevap vermektedir. Gazzâlî fevr görüşünü savunanların delilsiz ve keyfî bir iddiada bulunduklarını ileri sürmüş, onların nas kaynaklı hiçbir delil sunamayacaklarını, ancak dil bilimcilerin sözleriyle istişhat edebileceklerini ifade etmiş ve bunlara da itiraz ederek çeşitli açılardan cevaplar vermiştir. ${ }^{66}$ İbn Kudâme ise Gazzâlînin emrin fevr veya terâhîye delaleti ile ilgili meselede "emre uymakta hızlı davrananların övüldüğünü” gösterebilmek için zikrettiği delilleri kendisinin savunduğu fevr görüşüne uyarlamış, emrin dil bilimcilere göre fevri gerektirdiğini söylemiş ve Gazzâlînin eleştirdiği hususları yine kendi görüşünü desteklemek için kullanmıştır. Gazzâlînin görüşlerini "kavlühüm” (görüşleri/sözleri) ve görüşün zayıf olduğuna işaret eden "kïl" lafızlarıyla sunarak bu görüşlere de cevaplar vermiş, ayrıca meseleleri işlerken bazı takdim ve tehirlerle meselenin sistematiğini de kendi görüşüne göre şekillendirmiştir. ${ }^{67}$

Emrin bir sigaya sahip olup olmadığı ile ilgili meselede Gazzâlı̂ farklı görüşleri sıralayarak bu görüşlerle ilgili daha ihtiyatlı bir yaklaşım sergilemektedir. Gazzâlî̉ye göre bu hususta temeldeki ihtilaf noktası kelâm-1 nefsînin ${ }^{68}$ kabulü ile ilgilidir. Kelâm-1 nefsîyi kabul edenlere göre söz dilden çıkan şeydir ve emri ifade eden söz zatı ve cinsi açısından emir ve emredilmiş olan şey hakkındadır. Kelâm-ı nefsîyi inkâr edenler ise üç gruptur. İlk grup emrin harf ve ses dışında bir anlamı olmadığını; içinde fakihlerin de yer aldığı ikinci grup emir anlamının sadece siga ile değil bu siganın ibâha gibi farklı anlamlara geldiğine dair karinelerden mücerret olmasına bağlı olduğunu; içinde muhakkik Mu'tezilîler'in de bulunduğu üçüncü grup emir anlamının ancak emredilen şeyin, emir sigasının ve bu siganın emre delaletinin irade edilmesiyle ortaya çıkacağını iddia etmektedir. Fakat "Karinelerden mücerret olduğunda emrin

65 Bk. Gazzâlî, el-Mustasfâ, s. 211; İbn Kudâme, Ravzatün-nâzır, s. 238-40.

66 Gazzâlî, el-Mustasfâ, s. 215.

67 İbn Kudâme, Ravzatün-nâzır, s. 243-46.

68 Gazzâlî eserinin başka bir yerinde kelâm-1 nefsîyi (كلام النفس) söyleyenin maksadına bağlı olmaksızın anlamı kendi zatında ve cinsinde bulunan haber olarak tanımlamıştır (Gazzâlî, el-Mustasfâ, s. 106). 
emir olarak nitelenmesini sağlayan açık bir sigası vardır" görüşünü savunarak ikinci gruba yaklaşan İbn Kudâme, konu hakkındaki görüşleri Gazzâlî gibi gruplara ayırmadan kendi kanaatine muhalif olanların "bidatçı" olduğunu söylemekte ve görüşleri için ortaya koydukları, "Kelam, nefiste kaim olan bir mânadır" şeklindeki görüşü "hayal” olarak nitelemektedir. Daha sonra emir sigasının (yani if'al/إفعل ve bu kalıptaki bütün kelimelerin) müşterek (eş sesli) olup çeşitli anlamlara geldiği ve bu sebeple söz konusu anlamlar arasında bir tayin yapılarak bahsi geçen siganın emre mahsus olduğunu söylemenin bir tür "tahakküm” olduğu yönündeki karşı görüşün iki açıdan sahih olmadığını söylemektedir. İlki dilcilerin kullanımıdır. Zira dilciler çeşitli anlamlar için farklı sigalar ortaya koymuş ve emir sigasını emir anlamı için vazetmişlerdir. İkincisi ise tayin olmaması durumunda dilden elde edilen birçok faydanın ortadan kalkmasıdır. ${ }^{69}$

İbn Kudâme'nin emrin sigasıyla ilgili görüşü ve eleştirileri Hanbelîler'in Allah'nn kelam sıfatı ve halku'l-Kur'an görüşleriyle irtibatına dair önemli ipuçları vermektedir. Hanbelîler Allah’ın kelamını nefsî-lafzî diye bir ayırıma gitmeden harf ve seslerden ibaret görüp onun kategorik olarak kadim olduğunu savunmaktadır. Eş̧arîler’e göre ise kelâm-1 nefsî ve kelâm-1 lafzî şeklinde bir ayırım söz konusudur. Kelâm-ı nefsî Allah’’n zatıyla kaim bir mâna olup kadim iken kelâm-ı lafzî ilahî sözleri kullara ulaştıran harf ve seslerden ibarettir ve mahluktur. Dolayısıyla İbn Kudâme’nin "Kelam, nefiste kaim olan bir mânadır" şeklindeki görüşü "hayal” olarak nitelemesi Eşarîiler’in yaptıkları ayırıma ve kelamı Allahın zatıyla kaim olan bir mâna olarak kabul etmelerine bir cevap teşkil etmektedir. Zira kelam sıfatıyla ilgili böyle bir ayırıma gidilmesi Allahı̉n kelamının bir açıdan bile olsa mahluk olduğunu kabul etmek anlamina gelecek ve Hanbelîler'in Ahmed b. Hanbel'den itibaren tavizsiz bir şekilde Kur’an’ın mahluk olmadığı yönündeki görüşlerine aykırılık teşkil edecektir. ${ }^{70}$ Dolayısıyla İbn Kudâme’nin emir için belirlenmiş bir siganın olduğunu savunması Ravza'yı Hanbelî hassasiyetlere uygun bir eser haline getirme çabası açısından dikkat çekicidir.

Benzer bir durum tahsise uğradığını gösteren açık bir delil bulunmayan âm lafzın delaleti meselesinde de geçerlidir. Gazzâlî bu hususta tartışmaya mahal olmadığını söyleyecek kadar açık bir şekilde söz konusu lafzın umumuna hükmetmenin caiz olmadığını savunmaktadır. ${ }^{71} \mathrm{Bu}$ tür bir lafzın umumuna hükmedilmesi gerektiğini savunan İbn Kudâme ise Hanbelî mezhebi

69 Bk. Gazzâlî, el-Mustasfâ, s. 202-206; İbn Kudâme, Ravzatün-nâzır, s. 231-33.

70 Konuyla ilgili ayrıntılı bilgiler için bk. Yavuz, "Halku'l-Kur'ân”, s. 372-74; Altundağ,

"Kelâmullah- Halku'l-Kur'an Tartışmaları", 157-81.

71 Gazzâlî, el-Mustasfâ, s. 256-57. 
içerisindeki farklı kanaatleri aktardıktan sonra Gazzâlînnin görüşünü Şâfiîler’e nispet ederek zikretmiş ve kendi görüşünü temellendirmek için muhaliflere cevaplar vermiştir. Yukarıda da işaret edilen diğer meselelerde Gazzâlînin karşı görüş olarak zikrettiği delilleri kendi kanaatini desteklemek için kullanan İbn Kudâme, bu meselede farklı hareket etmiş ve bu sefer kendi görüşünü el-Mustasfầda yer almayan argümanlarla güçlendirmeye çalışmıştır. ${ }^{72}$

\section{c. İçtihat-Taklit Meseleleriyle İlgili Örnekler}

İçtihadda hata-isabet meselesinde Gazzâlî hatanın ve günahın birbirine zorunlu olarak bağlı olduğunu (mütelâzim) savunmaktadır. İtikadî konularda gerçeğin tek olduğunu ve dolayısıyla bu hususlarda yapılan içtihadda hata edenin günahkâr olacağını söylemektedir. Fakat hakkında kati delil bulunmayan fikhî meselelerde muayyen bir hüküm olmayıp her müçtehit isabet etmiş sayılır. İbn Kudâme ise Gazzâlînnin aksine hatayı ve günahı birbirinin mütelâzimi olarak görmemektedir. Bu sebeple hem itikadî hem de fikhî konularda sadece bir görüşün isabetli olduğunu bununla beraber fikhî konularda hatalı görüş beyan edenin günahkâr olmayacağını ifade etmektedir. Gazzâlînnin görüşünü “mütekellimîn”e atfederek yer veren İbn Kudâme, Gazzâlînin argümanlarını da zikredip bunlara da cevaplar vermiştir. ${ }^{73}$

Örneklerde görüldügü üzere İbn Kudâme, kendisinin ve mezhebinin Gazzâlîye muhalif olan görüşlerine eserinde yer vermekten çekinmemiştir. Üstelik bunu yaparken meselelerin vazedilişinde ve muhtelif görüşlerin zikredilmesinde farklı bir üslup ve yöntem takip ederek eserini hem Hanbelî bir kimliğe büründürmeye hem de el-Mustasfầnın bir ihtisarı olmaktan çıkarmaya çalışmıştır.

\section{Ravzatü'n-nâzır'in Hanbelî Kaynakları}

İbn Kudâme Ravza'nın Hanbelî bir kimliğe bürünmesini sağlamak amacıyla mezhep içerisinden pek çok isim ve esere de atıfta bulunmuştur. $\mathrm{Bu}$ isimlerin başında mezhebin ilk usul eserlerini kaleme almış olan ve mezhepte "Kādî" lakabıyla tanınan Ferrầ ${ }^{74}$ ile onun öğrencisi Kelvezânî̀ ${ }^{75}$ gelmektedir. Gazzâlînnin eserinde de mutlak olarak "Kādî" șeklinde yaptığı atıfların yer

72 İbn Kudâme, Ravzatün-nâzır, s. 282-84.

73 Bk. Gazzâlî, el-Mustasfâ, s. 357-53; İbn Kudâme, Ravzatün-nâzır, s. 414-22.

74 İbn Kudâme, mezhepte Ferrâ için yaygın bir şekilde kullanıldığ şekliyle "Kādî” diyerek atıfta bulunmuştur (bu atıfların bir kısmı için bk. İbn Kudâme, Ravzatü’n-nâzır, s. 62, $66,93,94,111,121,150,167,179,211,279,282,325,360,445)$.

75 Kelvezânîye yapılan atıfların bir kısmı için bk. İbn Kudâme, Ravzatü̉n-nâzır, s. 62, 111, 121, 135, 152, 175, 209, 240, 277, 305, 341, 381, 447. 
alması, İbn Kudâme’nin onu takip ederek aynı isme atıfta bulunduğu yanılg1sına yol açabilir. Fakat Gazzâlî "Kādî” lakabıyla Eş́arî usul ve kelam alimi Ebû Bekir el-Bâkıllânîyi, İbn Kudâme ise Ferrâyı kastetmektedir. Zira mutlak olarak kullanılan "Kādî" lakabı Eş̧arîler'de Ebû Bekir el-Bâkıllâni’yi, ${ }^{76}$ Hanbelîler'de Ferrâyı işaret etmektedir. ${ }^{77}$ Ayrıca Gazzâlî ile İbn Kudâme’nin bu şekilde atıfta bulunduğu mesele ve görüşlerin birbirinden farklı olması ve Ravza'da Kādîya nispet edilen görüşlerin Ferrânın el-Udde'sinde de bulunması İbn Kudâme’nin bu lakap ile Ferrầyı kastettiği hususunda şüpheye yer bırakmamaktadır. ${ }^{78}$

İbn Kudâme, Ferrâ ile Kelvezânî dışında Hırakī (ö. 334/946), ${ }^{79}$ Gulâmü’lHallâl olarak da bilinen Ebû Bekir b. Abdülazîz (ö. 363/974), ${ }^{80}$ Ebû İshak İbn Şâkillâ (ö. 369/979), ${ }^{81}$ Ebü'l-Hasan et-Temîmî (ö. 371/982), ${ }^{82}$ İbn Hâmid (ö. 403/1012) ${ }^{83}$ ve İbn Akīl (ö. 513/1119) $)^{84}$ gibi Hanbelî alimlerine de atıfta bulunur. Fakat şunu özellikle belirtmek gerekir ki Ferrâ ile Kelvezânî dışındaki isimlere yapılan atıflar toplam atıfların yaklaşık onda birini teşkil etmektedir.

Atıf yoğunlukları arasındaki bu farklılık, Ravza'nın bir usul eseri olması ve İbn Kudâme’nin de tabiatıyla kendisinden önce usule dair bir kitap kaleme almış olan alimlere müracaat etmek istemesiyle açıklanabilir. Nitekim bahsi geçen alimler arasında kaynaklarda usul kitabı telif ettiği nakledilen Ebü'lHasan et-Temîmî ile İbn Hâmid'in ${ }^{85}$ kitapları günümüze ulaşmamıştır. İbn Kudâme'nin bu kitapları görüp görmediği ve Ravza'da yaptığı atıfların onların bu eserlerinde yer alıp almadığını bilemiyoruz. Usul eseri kaleme almış bir diğer Hanbelî alimi İbn Akil'dir. Fakat İbn Kudâme İbn Akil'e sadece bir defa atıfta bulunmuştur. ${ }^{86}$ Atıf yoğunluklarındaki farklılık için yapılan bu değerlendirmeye paralel olarak mezhepte İbn Kudâme'den önce kaleme alınan üç önemli usul eserinden birinin müellifi olan İbn Akil'e de Ferrâ ve Kelvezânî kadar yer vermesi gerektiğini düşündürmektedir. Fakat İbn Kudâme’nin İbn

76 Bk. Gölcük, "Bâkıllânî”, s. 531.

77 Mezhepte mutlak olarak "Kādî” ifadesi Merdâvîye kadar sadece Ferrâ için kullanılmıştır (bk. Ebû Zeyd, el-Medhalül-mufassal, I, 213).

78 Karşılaştırmak için sırasıyla bk. İbn Kudâme, Ravzatünn-nâzır, s. 93, 179, 211, 226, 279, 282, 325, 445; Ebû Ya'lâ el-Ferrâ, el-Udde, III, 707; IV, 1105; I, 143; III, 725; II, 533; I, 339; IV, 1281; III, 1041.

79 Hırakīye yapılan atıflar için bk. İbn Kudâme, Ravzatünn-nâzır, s. 428, 439.

8o Atıflar için bk. İbn Kudâme, Ravzatün-nâzır, s. 226, 282, 291.

81 Bk. İbn Kudâme, Ravzatü’n-nâzır, s. 189, 292, 305.

82 Bk. İbn Kudâme, Ravzatün-nâzır, s. 66, 193, 226, 250, 319.

83 İbn Hâmid’e yapılan atıflar için bk. İbn Kudâme, Ravzatün-nâzır, s. 66, 226, 287.

84 İbn Akỉle yapılan atıf için bk. İbn Kudâme, Ravzatünn-nâzır, s. 94.

85 Bk. İbn Ebû Ya'lâ, Tabakātü'l-Hanâbile, III, 309.

86 Bk. İbn Kudâme, Ravzatün-nâzır, s. 94. 
Akîl’e karşı kaleme aldığı reddiye göz önünde bulundurulduğunda onun İbn Akil'den nakilde bulunmamayı özellikle tercih ettiği söylenebilir. Zira İbn Kudâme bu reddiyede İbn Akill'in ölümü için fetva verilmesine yol açan kelamî görüşlerine sert bir dille cevap vermektedir. İbn Kudâme’nin İbn Akill'in bu görüşlerinden tövbe ettiğini nakletmesine rağmen onun sadece görüşlerini eleştirmekle kalmayıp aynı zamanda şahsını da "miskin"87 ve "ahmak"88 gibi aşağılayıcı sıfatlarla tahkir etmesi ve görüşleri ile insanları kurtuluş yolundan saptırıp cehenneme sürüklediğini söylemesi, ${ }^{89}$ onun bu tövbenin samimiyetini sorguladığ şeklinde yorumlanabilir. ${ }^{90}$ Dolayısıyla kelamî görüşleri sebebiyle bu kadar sert bir şekilde eleştirdiği İbn Akille çok sınırlı bir şekilde atıfta bulunması, İbn Kudâme’nin kelamî unsurlardan arındırılmış bir usul kitabı kaleme alma amacının bir sonucu olmalıdır.

\section{Sistematik Farklılıklar}

İbn Kudâme sistematik olarak bazı tasarruflarda bulunarak eserinin $e l$ Mustasfẩdan farklı bir eser olduğunu göstermeye çalışmıştır. Gazzâlî, elMustasfầnın başında eserini mantık ilmine dair bir mukaddime ve dört ana bölüm şeklinde kurguladığını ifade etmiştir. Söz konusu mukaddimeden önce fıkıh usulünün tanım ve sınırlarını içeren ve mantık ile fikıh usulü arasındaki bağlantıya değinen bir giriş kaleme almıştır. Ana bölümleri "semere" (meyve/ ürün) metaforunu kullanarak taksim eden Gazzâlî fikıh usulünü hüküm ( $s e-$ mere), hükmün delilleri (müsmir), hüküm çıkarma yolları (turuku'l-istismâr) ve müçtehit (müstesmir) olmak üzere dört başlı̆̆a ayırmıştır. İbn Kudâme ise Gazzâlînin yaptığı dörtlü tasnifi takip etmeyerek mantık ilmine dair mukaddimenin ardından eserini sekiz baba ayıracağını ifade etmiştir. ${ }^{91}$ Burada zikrettiği bab isimlerinin bir kısmına eserin ilerleyen bölümlerinde yer vermese bile konuların sıralaması dikkate alındığında başta zikrettiği tasnif ile uyum içinde olduğu görülmektedir. İbn Kudâme üst ve alt başlıklarda farklı isimlendirmelere

87 İbn Kudâme, Tahrîmün-nazar, s. 42.

88 İbn Akil'in, "ahmak" ifadesini özetle "selefin görüşleri ile aldanan ve onları taklit eden kişiler” olarak tanımlaması üzerine İbn Kudâme, asıl ahmağın ashabın üzerinde icmâ ettiği ve sonraki nesillerin de buna tâbi olduğu görüşlere muhalif olan kişi olduğunu ifade ederek cevap vermiştir (İbn Kudâme, Tahrîmün-nazar, s. 42, 47).

89 Bk. İbn Kudâme, Tahrîmün-nazar, s. 47.

$90 \mathrm{Bu}$ reddiye için bk. İbn Kudâme, er-Red. Reddiyenin içeriği ile ilgili bir değerlendirme için bk. Onuş, VI.-VII. Asırlarda Dımaşk Hanbelîliği, s. 177-78. George Makdisi, İbn Akil'in ölümüne fetva verilmesine kadar giden tartışmalarda Ferrânın iki öğrencisi olan Şerîf Ebû Ca'fer ve İbn Akīl arasındaki rekabetin önemli ölçüde etkili olduğunu ifade etmektedir (bk. Makdisi, Ibn Aqil, s. 36-43).

91 İbn Kudâme, Ravzatün-nâzır, s. 26. 
gitse de konuların işlenişinde ve eserin genel tasnifinde el-Mustasfâ'dan tamamen farklılaştığını söylemek mümkün değildir. Nitekim üst başlıkların isimleri ve sayılarındaki bu farklılığa rağmen konuların sıralaması göz önünde bulundurulduğunda Ravza ile el-Mustasfâ arasındaki paralellik dikkat çekmektedir. ${ }^{92}$ Ayrıca müçtehit ve mukallit ile ilgili babda İbn Kudâme’nin müçtehidin yaptığı faaliyeti ifade ederken Gazzâlînnin "semere" metaforundan istifade ederek delillerden hüküm çıkarma işi için "istismar" (meyve/ürün elde etme) ifadesini kullanması Gazzâlînin etkisini göstermektedir. Bu paralelliğe rağmen eserinde tahsisin sınırı ile ilgili mesele dışında ${ }^{93}$ Gazzâlîye ve onun eserine hiç atıfta bulunmamasının yanında el-Mustasfầ daki dörtlü tasnifi göz ardı ederek farklı bir sistematik sunmayı tercih etmesi İbn Kudâme’nin -Tûfînin de ifade ettiği gibi- ${ }^{94}$ el-Mustasfầdan "müstakil" bir eser ortaya koyma amacının bir tezahürü olarak değerlendirilebilir.

\begin{tabular}{|c|c|}
\hline Gazzâlî, el-Mustasfâa $\hat{}^{95}$ & İbn Kudâme, Ravzatü’n-nâzur ${ }^{96}$ \\
\hline $\begin{array}{l}\text { Sadrü'l-kitâb: Usûl-i fikhın tanımı } \\
\text { ve diğer ilimlere ilişkisini içeren } \\
\text { giriş }\end{array}$ & Usûl-i fıkhın tanımı \\
\hline $\begin{array}{l}\text { Mukaddimetü'l-kitâb: Mantık ilmi- } \\
\text { ne dair mukaddime }\end{array}$ & Mukaddime \\
\hline Semere: Hüküm & Hükmün hakikati ve kısımları \\
\hline \multirow[t]{2}{*}{ Müsmir: Hükmün Delilleri } & $\begin{array}{l}\text { Asılların tafsili: Kitap, sünnet, icmâ ve } \\
\text { istishap }\end{array}$ \\
\hline & Hakkında ihtilaf edilen asılların beyanı \\
\hline \multirow{3}{*}{$\begin{array}{l}\text { Turuku’l-istismâr: Hüküm Çıkarma } \\
\text { Yolları }\end{array}$} & Söz ve isimlerin kısımları \\
\hline & $\begin{array}{l}\text { Emir, nehiy, umum, istisna, şart ve la- } \\
\text { fızların işaret ve imasından çıkarılanlar }\end{array}$ \\
\hline & Asılların fer'i konumunda olan kıyas \\
\hline \multirow{2}{*}{ Müstesmir: Müçtehit } & $\begin{array}{l}\text { Bu delillerden hüküm istismar eden } \\
\text { müçtehit ve mukallit }\end{array}$ \\
\hline & $\begin{array}{l}\text { Teâruz halindeki deliller arasındaki } \\
\text { tercih }\end{array}$ \\
\hline
\end{tabular}

Tablo 1: el-Mustasfâ ve Ravza'nın müellifleri tarafından verilen tasnifi

92 Her iki müellifin tasnifine ve Ravza'da farklı sayı ve isimle verilen başlıkların elMustasfầda hangi başlık altında işlendiğine Tablo 1'de yer verilmiştir.

93 Bk. İbn Kudâme, Ravzatün-nâzır, s. 281.

94 Bk. Tûfî, Şerh, I, 98.

95 Bk. Gazzâlî, el-Mustasfâ, s. 5, 7-9.

96 Bk. İbn Kudâme, Ravzatün-nâzır, s. 26. 
İki eser arasında üst başlıkların isimlendirilmesindeki farklılıklar, daha alt seviyede bu başlıkların altında yer alan meseleler işlenirken de dikkat çekmektedir. İbn Kudâme, eserinin temel yapısını el-Mustasfầdan çok farklılaştırmasa da bir konu altındaki meseleleri işlerken bazı takdim ve tehirlerde bulunmuştur. Mesela istihsan bahsinde Gazzâlî, istihsanın üç farklı anlamına yer verirken her bir anlama dair delilleri ve itirazları ilgili anlamın hemen sonrasına yerleştirmiştir. ${ }^{97}$ İbn Kudâme de istihsanın üç anlamına yer vermesine rağmen Gazzâlînnin üçüncü sırada zikrettiğine ilk sırada; ilk sırada zikrettiğine ikinci sırada; ikinci sırada zikrettiğine ise üçüncü sırada yer vererek el-Mustasfâ'dan tamamıyla farklılaşmıştır. ${ }^{98}$ Ayrıca ilk sırada zikrettiği "kitap veya sünnet gibi özel bir delil sebebiyle bir meselede o meselenin benzerlerine verilen hükümden vazgeçmek" şeklinde tanımlanan istihsanın bu anlamıyla Hanbelî mezhebinde de kabul edildiğine dair nakilde bulunmuştur. Üstelik İbn Kudâme’nin diğer iki tanıma Gazzâlînnin ifadelerini özetleyerek yer vermesine rağmen burada tamamen müstakil davranarak bu tanımı ilk sırada zikretme sebebinin Hanbelî mezhebindeki genel kabul ile bağlantılı olduğuna işaret etmektedir.

Karinelerden soyutlanmış olarak gelen emrin delaleti meselesinde de İbn Kudâme meseleyi sunarken farklı bir yol takip etmiştir. Gazzâlî meseleye emrin sigası bağlamında değinmiş ve bu husustaki kullanımlara yer vermiştir. Karinelerden mücerret haldeki emrin delaleti ile ilgili ilk olarak genel bilgiler veren Gazzâlî daha sonra mesele ile ilgili görüşleri ve bu görüşlerin gerekçelerini sıralayıp muhalif gördüklerine cevaplar vermiştir. ${ }^{99}$ İbn Kudâme ise Gazzâlînin görüşlere yer verirken gözettiği sıralamayı takip etmediği gibi sadece görüşleri vermekle yetinmiş, nadiren bazı cevapları zikretmiştir. İbn Kudâme’nin bu meseledeki asıl farklılığ karinelerden soyutlanmış emrin vücuba delalet ettiği şeklindeki mezhep görüşüne yer verdiği kısımdır. İbn Kudâme burada görüşün belirlenmesi hususunda kitaba, sünnete, icmấa ve lisan ehlinin sözlerine itibar edilmesi gerektiğini ifade ederek görüşünü destekleyici delilleri sıralamıştır. Gazzâlînin "Emir vücuba delalet eder" şeklindeki görüş için zikrettiği delilleri İbn Kudâme burada farklı bir bağlam içerisinde kendi görüşünü desteklemek için kullanmıştır. ${ }^{100}$

97 Gazzâlî, el-Mustasfâ, s. 172-73.

98 İbn Kudâme, Ravzatün-nâzır, s. 200-202.

99 Gazzâlî, el-Mustasfâ, s. 204-11.

100 İbn Kudâme, Ravzatün-nâzır, s. 236-37. Karşılaştırmak için bk. Gazzâlî, el-Mustasfâ, s. 208-209. 
İç tasnifteki tasarruflar şebeh kıyasında ${ }^{101}$ daha bariz bir hal almakta ve İbn Kudâme bu bahiste Gazzâlîye nispetle daha sistematik bir yol takip etmektedir. İbn Kudâme, meseleye el-Mustasfầda yer almayan Hanbelîler'in şebeh kıyasına dair tanımı ve bu tanıma ilişkin örneklerle başlamıştır. Gazzâlî aslın hükmünün fer'e verilmesini sağlayan vasıf olan illetle ilgili açıklamalarda bulunurken herhangi bir taksim yapmadan şebehin, $\operatorname{tard}^{102}$ ve münasipten ${ }^{103}$ farkını anlatmaktadır. ${ }^{104}$ İbn Kudâme ise bunların illetin alt kısımları olduğunu ifade ederek illeti üç kısma ayırmıș ve Gazzâlîden farklı bir sıralama takip ederek münasip, tard ve şebehi ayrı ayrı açılamayı tercih etmiştir. Daha sonra yaptığı taksimi devam ettirerek ilk sırada yer verdiği illet kıyasının sahih, ikinci sıradaki tardın batıl ve üçüncü sıradaki şebeh kıyasının ihtilaflı olduğunu belirtmiştir. ${ }^{105}$ Şebeh kıyasının sıhhati için zikredilen deliller kısmında iki müellif neredeyse tamamen farklılaşmaktadır. Gazzâlî buradaki delilleri cedel ve münazara formatında verirken, İbn Kudâme Ahmed b. Hanbel'den gelen nakilleri sıralamış ve şebeh kıyasının hüccet olarak kabul edilmesinin gerekçelerini kısaca açıklamıştır. Böylece el-Mustasfầdan farklılaşmış ve meseleyi farklı bir bakış açısıyla ortaya koymaya çalışmıştır. ${ }^{106}$

\section{Sonuç Yerine}

Hanbelî mezhebi teşekkül döneminden itibaren kelama mesafeli bir tavır içerisinde olmuş ve bu tavır kelamla yakından irtibatlı bir ilmî disiplin olması açısından usûl-i fikıh alanında da mezhep müntesipleri için bir ilgi eksikliğinin ortaya çıkmasının sebepleri arasında yer almıştır. Zira Ahmed b. Hanbel ve takipçileri Allah’n zat ve sıfatları ile ilgili kelamî meselelerde "bilâkeyf"

101 Gazzâlî şebeh kıyasını "illet olmadığı bilinen bir vasıf sebebiyle asıl ile fer'i birleștirmek” şeklinde tanımlamıştır (Gazzâlî, el-Mustasfâ, s. 317). İbn Kudâme ise Hanbelî alimi Kādî Ya‘kūb b. İbrâhim’den (ö. 486/1093) nakille fer'in yasaklayıcı ve mübah kılıcı iki asıl arasında yer alıp bunlardan birine daha fazla benzemesi durumunda şebeh kıyasının söz konusu olduğunu ifade etmiştir (İbn Kudâme, Ravzatünn-nâzır, s. 358). Şebeh kıyasının hüccet olmasıyla ilgili farklı görüşler mevcuttur (ayrıntılar için bk. Kısıkkaya, İslam Hukuk Usulünde Kıyas-ı Şebeh, s. 27-41).

102 Bir vasfın bulunması halinde hükmün de bulunması durumuna tard denmektedir. Söz konusu vasfın bulunduğu meselelerde hükmün de ortaya çıktığı gösterilerek bu vasfın aynı zamanda illet olduğu sonucuna varılır (Başoğlu, "İlleti Tespit Metotlarından Tard”, s. 141-42). Gazzâlî, ittıradın kıyastaki asıl ve fer'i bir araya getiren bütün illetlerin şartı olduğunu söylemektedir (Gazzâlî, el-Mustasfâ, s. 316).

103 Münasebet, kıyasta hüküm ve illet arasındaki uygunluk için kullanılan bir kavramdır. Bir vasfın illet olabilmesi için hükme münasip olması gerekir (bk. Apaydın, "Kiyas", s. 535).

104 Gazzâlî, el-Mustasfâ, s. 317 .

105 İbn Kudâme, Ravzatün-nâzır, s. 358-59.

106 Gazzâlî, el-Mustasfâ, s. 318-19; İbn Kudâme, Ravzatün-nâzır, s. 360-61. 
iman ve "sükût" etme ilkesini benimsemiş ve Hanbelîler Sünnî mezhepler içerisinde büyük ölçüde bu özellikleri ile temayüz etmişlerdir. Mezhep içerisinde istisnaî bir biçimde kelamla yakından ilgilenen bazı alimlerce telif edildiği söylenen ilk usul eserlerinin mezhep müntesipleri nezdinde yeterince itibar görmemesinin muhtemel sebepleri arasında bu eserlerin kelamî tartışmaları hâvi olmaları önemli bir yer tutmaktadır. Usûl-i fikha dair ilginin arttığına dair ilk işaretler Ferrâ ve ashabı ile birlikte ortaya çıkmış olsa da bu alimlerin kaleme aldıkları eserler de yine kelamî referansları içeren birçok eleştiriye maruz kalmış ve mezhepte uzun soluklu ve yaygın bir etkiye sahip olamamiştır.

Hanbelî mezhebinde bir usûl-i fikıh eserinin önceki dönemlere nispetle daha yaygın bir şekilde tedris faaliyetlerine konu olması ve kabul görmesi, İbn Kudâme’nin Ravza adlı eseriyle başlamıştır. Ravza'nın esasında Eş́arî geleneğin önemli isimleri arasında yer alan Gazzâlînin el-Mustasfầsına dayanması, İbn Kudâme’nin bu eseriyle Hanbelî mezhebinde kelama karşı olan köklü direnişi kırdığını ve usûl-i fikha karşı olan ilgi eksikliğini ortadan kaldırdığını akla getirebilir. Mamafih bu durum mezhepte usûl-i fikha karşı olan ilgi eksikliğini giderme hususunda kayda değer katkılar sağlamış olmakla beraber kelama karşı ancak nisbî denebilecek bir yumuşamayı temsil etmektedir. Nitekim eserde İbn Kudâme'nin mezhebin geleneksel ilkelerine sadık kaldığını gösteren birçok işaret mevcuttur. İbn Kudâme, eserde içerik ve tasnif açısından yaptığı tasarruflarıyla Ravza'yı el-Mustasfầnın gölgesinden kurtarmaya çalışmıs ve böylece eserine Hanbelî kimliği kazandırmaya çalışmıştır.

İbn Kudâme’nin en dikkat çekici tasarrufları kelamî meselelerle ilgili olmuştur. Gazzâlî her ne kadar eserinin başında usûl-i fikha kelamî meselelerin karıştırılmaması gerektiğini ifade etmiş ve eserini buna dikkat ederek kaleme aldığını söylemiş olsa da eserinde kelamî bazı meselelere ve örneklere rastlamak mümkündür. İbn Kudâme eserin birçok yerinde Gazzâlîden iktibaslarda bulunmasına rağmen kelamî uzantıları olan meseleler ve örnekler konusunda seçici davranarak bunları göz ardı etmiştir. Bu tavır Ravza'yı kendisinden önce Hanbelîler tarafından kaleme alınan usul eserlerinden ayıran en önemli hususiyet olarak zikredilebilir. Önceki eserlerin kelamî bazı uzantıları barındırmasından dolayı mezhepte yaygın bir etkiye sahip olmaması göz önünde bulundurulduğunda Ravza'nın mezhepte kabul görmesi ve okutulmasındaki en büyük etkenlerden biri olarak İbn Kudâme’nin Hanbelî mezhebinin kelamî meselelerle ilgili "sükût" ve "bilâkeyf" iman etme ilkelerini gözeterek bir usul eseri ortaya çıarması gösterilebilir. Zira böylece ilk defa mezhebin geleneksel çizgisiyle uyumlu bir usul eseri kaleme alınmıştır. Buna rağmen İbn Kudâme’nin Eşarâi geleneği temsil eden bir eseri esas almış olması Eşarîi 
düşüncenin Ehl-i sünnet geleneğinin entelektüel faaliyetlerinin yürütüldügü neredeyse tek alan haline gelmesiyle ve İbn Kudâme’nin yaşadığ dönemde ve coğrafyada bu düşüncenin en güçlü temsilcisi konumunda olan Şâfiîler'in baskın etkisinin oluşturduğu ilmî ortamın yönlendirmesiyle açıklanabilir.

Sistematik olarak tasnifin temel yapısında iki eser arasında bir uyum göze çarpsa da İbn Kudâme’nin el-Mustasfầdaki dörtlü tasnifi terketmesi ve meselelerin işlenişinde bazı takdim ve tehirlerde bulunması da dikkat çekicidir. İbn Kudâme'nin yaptığı bu tasarruflar, Ravza'nın el-Mustasfẩnın bir ihtisarı olarak değerlendirmesinin önüne geçme ve ilk bakışta müstakil bir eser izlenimi uyandırma amacı taşıyor gibidir. Zira İbn Kudâme eserinde temel kaynak olarak ne Gazzâlîden ne de eserinden bahsetmektedir. Buna ek olarak birçok meselede Hanbelî isimlere atıfta bulunmuş, mezhep içindeki farklı görüşleri tartışarak değerlendirmiştir. Bazı durumlarda isim vermeden Gazzâlînnin delillerine ve argümanlarına karşı kendisinin ve mezhebinin görüşünü savunmuş, muhalif görüşlere cevaplar vermiştir. İbn Kudâme’nin bu tasarrufları sadece eserini el-Mustasfầdan farklılaştırma amacına hizmet etmemiş, aynı zamanda -Tûfîye göre- işlediği konuları ve genel olarak eserini Eş̧arî-Şâfîi gelenekten ayrıştırıp "Hanbelî-Eserî" bir çizgiye yerleştirmesine yardımcı olmuştur. Bu sebeplerle Ravza'nın el-Mustasfầnın mahzâ bir ihtisarı olduğu şeklindeki kanaatler sorgulanmalı, eserin Eş̧arî gelenekle ve felsefe-mantık ile olan irtibatının mahiyeti daha dikkatli bir şekilde incelenmelidir. Yukarıdaki tespitlere rağmen İbn Kudâme’nin bu eserinin az sayıda kelamî meseleleri de içermesi bakımından sonraki dönem Hanbelî usul eserlerine ve mezhebin kelam ilmine yaklaşımının yeniden şekillenmesine ne derece etki ettiği sorusu vuzuha kavuşturulması gereken önemli bir araştırma sorusu olarak durmaktadır. Ayrıca yukarıda Hanbelîler'in usûl-i fıkha dair "ilgi eksikliği”" olarak değerlendirilen tavırlarının bu disiplinin bizatihi kendisine mi yoksa ilgili dönemlerde usûl-i fikıh ilminin ele alındığı zeminin mezhep müntesipleri içinde oluşturduğu intiba sebebiyle mi olduğu müstakil ve ayrıntılı bir şekilde de incelenerek daha açık bir şekilde ortaya konmalıdır. 


\section{Bibliyografya}

Altundağ, Mustafa, "Kelâmullah - Halku'l-Kur'an Tartışmaları Çerçevesinde "Kelam-1 Nefsî - Kelâm-1 Lafzî” Ayrımı”, Marmara Üniversitesi İlâhiyat Fakültesi Dergisi, 18 (2000): 149-181.

Apaydın, Yunus, “Kıyas”, DİA, 2002, XXV, 529-539.

Aslan, İbrahim, “el-Usūlu’l-Hamse’nin Hanbelī Yorumu: el-Kādī Ebū Ya 'lā el-Ferrā Örneği”, Ankara Üniversitesi İlâhiyat Fakültesi Dergisi, 53/1 (2012): 55-83.

Başoğlu, Tuncay, Hicrî Beşinci Asır Fıkıh Usûlü Eserlerinde İllet Tartışmaları (doktora tezi), Marmara Üniversitesi, 2001.

Başoğlu, Tuncay, “illeti Tespit Metotlarından Tard ve Tard Ehline Yönelik Tenkitler”, Sakarya Üniversitesi İlâhiyat Fakültesi Dergisi, 6 (2002): 141-159.

Bedir, Murteza, “er-Risâle”, DİA, 2008, XXXV, 117-119.

Çalış, Halit, "Kâsır İlletle Ta 'lil Tartışmalarına Metodolojik Bir Katkı”, Usûl: İslâm Araştırmalar, 4 (2005): 73-98.

Dede, Nusret, İbn Kudâme Penceresinden Fıkıh Usûlü, İstanbul: Rağbet Yayınları, 2017.

Dönmez, İbrahim Kâfi - Asım Cüneyd Köksal, “Usûl-i Fıkıh”, İbrahim Kâfi Dönmez, Fıkıh Usulü İncelemeleri içinde, İstanbul: İsam Yayınları, 2014, s. 19-52.

Dönmez, İbrahim Kâfi - Asım Cüneyd Köksal, “Usûl-i Fıkıh”, DİA, 2012, XLII, 201-210.

Ebû Ya'lâ el-Ferrâ, el-Udde fî usûli’l-fikh, nşr. Ahmed b. Ali Seyr el-Mübârekî, I-V, Riyad: y.y., 1410/1990.

Ebû Zeyd, Bekir b. Abdullah, el-Medhalül-mufassal ilâ mezhebil-İmâm Ahmed b. Hanbel, I-II, Riyad: Dârü'l-âsıme, 1417/1997.

Gazzâlî, el-Mustasfâ, nşr. M. Abdüsselâm Abdüşşâfî, Beyrut: Dârü’l-kütübi'l-ilmiyye, $1413 / 1993$.

Gazzâlî, Mustasfâ: İslâm Hukukunun Kaynakları, çev. Yunus Apaydın, İstanbul: Klasik Yayınları, 2017.

Gölcük, Şerafettin, “Bâkıllânı̂”, DİA, 1991, IV, 531-535.

Hatîb el-Bağdâdî, Târîhu Bağdâd, nşr. Beşşâr Avvâd Ma'rûf, I-XVII, Beyrut: Dârü'l-garbi'lİslâmî, 1422/2002.

İbn Akīl, Ebüll-Vefâ, el-Vâzıh fî usûliłl-fikh, nşr. G. Makdisi, Stuttgart: Franz Steiner Verlag, t.y.

İbn Akīl, Ebü'l-Vefâ, el-Vâzıh fî usûli'l-fikh, nşr. Abdullah b. Abdülmuhsin et-Türkî, I-V, Beyrut: Müessesetürr-risâle, 1420/1999.

İbn Bedrân, Abdülkādir, el-Medhal ilâ mezhebi'l-İmâm Ahmed, nşr. Abdullah b. Abdülmuhsin et-Türkî, Beyrut: Müessesetürr-risâle, 1401/1981.

İbn Bedrân, Abdülkādir, Nüzhetül-hâtıri'l-âtır, I-II, Beyrut: Dârü’l-hadîs, 1416/1991.

İbn Ebû Ya'lâ, Tabakātü'l-Hanâbile, nşr. Abdurrahman b. Süleyman el-Useymîn, I-III, Riyad: el-Emânetü'l-âmme li'l-ihtilâf, 1419/1999.

İbn Hâmid, Tehzîbü’l-ecvibe, nşr. Abdülazîz b. Muhammed el-Kāyidî, Medine: Mektebetü’lulûm ve'l-hikem, 1425. 
İbn Hâmid, Tehzîbül-ecvibe, nşr. Subhî es-Sâmerrâî, Beyrut: Âlemü'l-kütüb - Mektebetü’nnehdati'l-Arabiyye, 1408/1988.

İbn Kudâme, Muvaffakuddin, er-Red alâ İbn Akīl el-Hanbelî, nşr. Ahmed Ferîd el-Mezîdî, Beyrut: Dârü'l-kütübi'l-ilmiyye, 1425/2004.

İbn Kudâme, Muvaffakuddin, Ravzatünn-nâzır, nşr. M. Mirâbî, Dımaşk-Beyrut: Müessesetü’r-risâle, 1430/2009.

İbn Kudâme, Muvaffakuddin, Ravzatün-nâzır, nşr. Abdülkerîm b. Alî Nemle, I-III, Riyâd: Mektebetürr-rüşd, 1413/1993.

İbn Kudâme, Muvaffakuddin, Tahrîmün-nazar fî kütübi'l-kelâm, nşr. Abdurrahman b. Muhammed Saîd Dımaşkıyye, Riyad: Dâru âlemi'l-kütüb, 1410/1990.

İbn Receb, Zeylü Tabakāti'l-Hanâbile, nşr. Abdurrahman b. Süleyman b. Muhammed elUseymîn, Riyad: Mektebetü'l-Ubeykân, 1425/2005.

İbn Teymiyye, Takıyyüddin, Mecmûu'l-fetâvâ, nşr. Abdurrahman b. Muhammed b. Kāsım, Medine: Mecmaü'l-Melik Fehd li’t-tıbâati'l-Mushafi’ş-şerîf, 1436/1995.

İbn Teymiyye, Takıyyüddin, el-Müsevvede fî usûli’l-fikh, nşr. M. Muhyiddin Abdülhamîd, Beyrut: Dârü'l-kitâbi'l-Arabî, t.y.

İbnü'l-Esîr, İzzeddin, el-Kâmil, nşr. Ebü’l-Fidâ Abdullah el-Kādî - M. Yûsuf ed-Dekkāk, I-X, Beyrut: Dârü'l-Kütübi'l-İlmiyye, 1407/1987.

İbrâhim b. Abdullah, “Tedvînü usûli'l-fikh inde'l-Hanâbile”, Mecelletü Câmiati'l-İmâm Muhammed, 20 (1418): 121-162.

Kaya, Eyyüp Said, “Mâlikî Mezhebi”, DİA, 2003, XXVII, 519-535.

Kaya, Eyyüp Said, Mezheblerin Teșekkülünden Sonra Fıkhî İstidlâl (doktora tezi), Marmara Üniversitesi, 2001.

Kaya, Eyyüp Said, “Mütekaddimîn ve Müteahhirîn”, DİA, 2006, XXXII, 188-189.

Kāyidî, Abdülazîz b. Muhammed, "el-Mukaddime”, İbn Hâmid, Tehzîbü’l-ecvibe nşr. Abdülazîz b. Muhammed el-Kāyidî, içinde, s. 13-23.

Kısıkkaya, Ömer Tekin, İslam Hukuk Usulünde Kıyas-ı Şebeh ve Bir Hüküm Çıkarma Yöntemi Olarak Değeri (yüksek lisans tezi), Erciyes Üniversitesi, 2010.

Koca, Ferhat, "Hanbelî Mezhebi”, DİA, 1997, XV, 525-547.

Koca, Ferhat, İslam Hukuk Tarihinde Selefî Söylem: Hanbelî Mezhebi, İstanbul: Ankara Okulu Yayınları, 2011.

Koca, Ferhat, “Ravzatün-nâzır”, DİA, 2007, XXXIV, 476-477.

Makdisi, G., Ibn 'Aqil: Religion and Culture in Classical Islam, Edinburgh: Edinburgh University Press, 1997.

Makdisi, G., "Mukaddimetü'l-muhakkık” İbn Akìl, Ebü'l-Vefâ, el-Vâzıh fî usûli'l-fikh, nşr. G. Makdisi içinde, II, m1-m2; III, m1-m2.

Mirâbî, Muhammed, “Mukaddimetü'l-mu'tenî”, İbn Kudâme, Muvaffakuddin, Ravzatünnâzır, nşr. M. Mirâbî içinde, s. 6-25.

Mübârekî, Ahmed b. Ali Seyr, “Mukaddime”, Ebû Ya 'lâ el-Ferrâ, el-Udde fì usûli'l-fikh içinde, s. 7-60. 
Nemle, Abdülkerîm b. Alî, "el-Mukaddime”, İbn Kudâme, Ravzatün-nâzır, nşr. Abdülkerim b. Alî Nemle içinde, I, 3-52.

Onuş, Muhammed Usame, Hirakînin el-Muhtasar’ı ve Hanbelî Mezhebine Etkisi (yüksek lisans tezi), Marmara Üniversitesi, 2013.

Onuş, Muhammed Usame, VI.-VII. Asırlarda Dımaşk Hanbelîliği (doktora tezi), Marmara Üniversitesi, 2020.

Özel, Ahmet, “Hanefî Mezhebi”, DİA, 1997, XVI, 21-27.

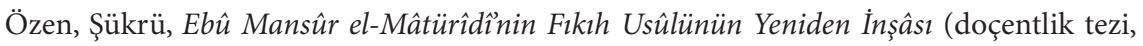
2001), İSAM Ktp., nr. 95434.

Özmen, Ramazan, "Doğuşundan Tedvînine Hanbelî Fıkıh Usûlü Geleneği ve Özgünlük Sorunu”, İslam Hukuku Araştırmaları Dergisi, 11 (2008): 189-216.

Safedî, el-Vâfî biłl-vefeyât, nşr. Ahmed el-Arnâut - Türkî Mustafa, I-XXIX, Beyrut: Dâru ihyâi't-türâsi'l-Arabî, 1420/2000.

Sa îd, Abdülazîz b. Abdurrahmân, İbn Kudâme ve âsâruhu'l-usûliyye, Riyad: Câmi'atü'lİmam Muhammed b. Su'ûd el-İslâmiyye, 1408/1987.

Sâlim, Atıyye Muhammed, “Mukaddime”, Şinkītî, Müzekkire fî usûlil-fikh içinde, s. 3-8.

Sâmerrâî, Subhî, "Mukaddimetü’l-muhakkık", İbn Hâmid, Tehzîbü’l-ecvibe, nşr. Subhî esSâmerrâî içinde, s. 5-13.

Şinkītî, Muhammed Emîn, Müzekkire fî usûli'l-fikh, Medine: Mektebetü’l-ulûm ve'l-hikem, 2001.

Tûfî, Şerhu Muhtasari'r-Ravza, nşr. Abdullah b. Abdülmuhsin et-Türkî, I-III, Beyrut: Müessesetürr-risâle, 1419/1998.

Ukberî, Ebû Ali, Risâle fî usûli'l-fikh, nşr. Bedr b. Nâsır es-Sübey'î, Amman: Ervika lidddirâse ve’n-neşr, 1438/2017.

Yavuz, Yusuf Şevki, “Halku'l-Kur'ân”, DİA, 1997, XV, 371-375.

Yılmaz, Abdülkadir, "Hanefi Mezhebinin Rical ve Kitabiyatına Dair Bazı Tetkikat”, Rıhle, 12 (2011): 61-66.

Zehebî, Târîhu'l-İslâm, nşr. Beşşâr Avvâd Ma'rûf, I-XVII, Beyrut: Dârü'l-garbi'l-İslâmî, $1424 / 2003$.

Ziriklî, el-A ‘lâm, I-VIII, Beyrut: Dârü’l-ilm li’l-Melâyîn, 2002. 


\section{A Summary or an Independent Work?}

\section{An Inquiry on the Connection Between Rawdat al-nāzir and al-Mustasfā}

The Hanbali school of law has, since its formation, been distinct in its approach to the juristic methodology and theology. While the juristic activities of the other schools of law can be traced back to early Islamic history, the first remarkable juristic effort of the Hanbali school appeared only in the first half of the fifth/ eleventh century. The first complete work on the principles of Islamic jurisprudence, titled al-'Uddah fì ușūl al-fiqh by Abū Ya'lā al-Farrā', was a product of this effort. Farrā”s students advanced this effort; Abū al-Khațāa al-Kalwadhānī’s (d. 510/1116) al-Tamhìd fì ușül al-fiqh and Abū al-Wafä Ibn 'Aqīl's (d. 513/1119) alWädih fì uṣul al-fiqh grew into prominent works within the school. These three works, which did not have a long-lasting impact on the Hanbali school, seem to have been written based on works in the Mu'tazilī and Ash'arī traditions. In addition, we do not have sufficient information to determine whether these sources were adopted as textbooks or were the subject of commentary or summary. This fact may be because these works include certain issues that contradict the distanced attitude of the Hanbalis to theological problems or because they were based on certain books authored by scholars and groups who have traditionally been opponents of the Hanbalis. In addition to these three works, many works on the principles of Islamic jurisprudence were authored by Hanbali scholars, a majority of whom were Farrā"s students, until Muwaffaq al-Dīn Ibn Qudāma (d. 620/1223) wrote Rawdat al-näzir. However, as these works have not survived to the present, we find limited information on their contents in relevant sources. This fact shows that the focus by "Farrä' and his students" on the principles of Islamic jurisprudence should not be viewed as representative of the general Hanbali school of law, and that a lack of interest in legal issues mixed with theological issues still persists.

The fact that Ibn Qudāma's Rawda was based on al-Mustaşfā by al-Ghazālī, who was one of the most prominent representatives of the Ash'ari school, raised questions on the nature of Ibn Qudāma's use of al-Mustasfä. While some scholars hold that Rawda was a summary of al-Mustasfāa, some view it as more than merely a summary of al-Mustasfā despite an extensive resemblance between the two texts. In any case, all concur that Rawda was principally based on al-Mustasfā. Therefore, one may expect that Rawda would receive similar reactions as previous works on the principles of Islamic law because of its reliance on a work in the Ash'arī school. However, even though Ibn Qudāma has been criticized for his inclusion of an introduction on logic by following Ghazāī, Rawda, unlike previous works, was received positively by the school and was adopted as a textbook in teaching. This could be because the author tried to save Raw da from the shadow of al-Mustaşa by making interventions related to its content and classifications; he thereby dressed up his work with a Hanbali identity. He chose to be selective in addressing issues with theological connotations and respected the sensitivities of his school. He reordered issues discussed in al-Mustasfā and added previous Hanbali scholars' views on the principles of Islamic law. 
The most remarkable interventions in Rawda were related to theological issues. Even though Ibn Qudāma quoted from Ghazālī on many occasions, he disregarded Ghazālī and remained selective while discussing certain issues with theological connotations. This attitude distinguishes Rawda from the works penned by previous Hanbali scholars. Considering the fact that previous works containing theological discussions held a marginal place within the school, one of the most critical factors for Rawda's positive reception and its adoption as a textbook may have been that Ibn Qudāma wrote a book on the principles of the Islamic law by observing the Hanbali principle of believing by "sukūt (silence)" and "bilā kayf (without asking 'how')." Therefore, a book on the principles of the Islamic law that conformed with the school's traditional line appeared for the first time. Further, Ibn Qudāma's reliance on a work in the Ash'arī school can be explained by the fact that Asharī thought held a unique place as a field for intellectual discussions among the Sunnis. In addition, a scholarly milieu shaped by the powerful Shāfi'i scholars existed in the time and place Ibn Qudāma lived.

Concerning the organization of the book-and diverging from Ghazālīs quadruple classification-Ibn Qudāma stated after the introduction on logic that he organized his book under eight headings. Although some of the headings he mentioned do not appear inside the book, his initial organization seems to conform with the overall content of the book. Despite different headings and sub-headings, it is worth noting Ibn Qudāma's divergence from al-Mustaşfä's quadruple classification and ordering of chapters. These changes seem to suggest that Ibn Qudāma intended his work not to be read as a mere summary of al-Mustasffá , but as an independent work.

Ibn Qudāma cited many names and works in the school to reinforce Rawda's Hanbali identity. He never mentioned Ghazālī or cited his book, even though he principally relied on it. Occasionally he defended his and the school's positions against Ghazālìs arguments and proofs, but did so without mentioning him. These interventions not only served to differentiate Ibn Qudāma’s book from al-Mustașāa but also helped to position his book along a "Hanbali-Ash'arī" line by diverging from the "Ash'arī-Shāficî̀" one.

Keywords: Ibn Qudāma, Rawdat al-nāzir, Hanbali school of law, principles of the Islamic law, Ghazālī, al-Mustașfā. 